\title{
Selection markers for transformation of the sequenced reference monokaryon Okayama 7/\#130 and homokaryon AmutBmut of Coprinopsis cinerea
}

\author{
Bastian Dörnte ${ }^{1}$, Can Peng ${ }^{3,4}$, Zemin Fang $^{3,4}$, Aysha Kamran ${ }^{1,5}$, Cut Yulvizar ${ }^{1}$ and Ursula Kües 12*0 $^{12^{*}}$
}

\begin{abstract}
Background: Two reference strains have been sequenced from the mushroom Coprinopsis cinerea, monokaryon Okayama 7/\#130 (OK130) and the self-compatible homokaryon AmutBmut. An adenine-auxotrophy in OK130 (ade81) and a para-aminobenzoic acid (PABA)-auxotrophy in AmutBmut (pab1-1) offer selection markers for transformations. Of these two strains, homokaryon AmutBmut had been transformed before to PABA-prototrophy and with the bacterial hygromycin resistance marker $h p h$, respectively.

Results: Gene ade8 encodes a bifunctional enzyme with an N-terminal glycinamide ribonucleotide synthase (GARS) and a C-terminal aminoimidazole ribonucleotide synthase (AIRS) domain required for steps 2 and 5 in the de novo biosynthesis of purines, respectively. In OK130, a missense mutation in ade8-1 rendered residue N231 for ribose recognition by the A loop of the GARS domain into D231. The new ade $8^{+}$vector pCcAde8 complements the auxotrophy of OK130 in transformations. Transformation rates with pCcAde8 in single-vector and co-transformations with ade $8^{+}-$ selection were similarly high, unlike for $\operatorname{trp} 1^{+}$plasmids which exhibit suicidal feedback-effects in single-vector transformations with complementation of tryptophan synthase defects. As various other plasmids, unselected pCcAde8 helped in co-transformations of trp 1 strains with a trp $1^{+}$-selection vector to overcome suicidal effects by transferred $\operatorname{trp~}^{+}$. Co-transformation rates of pCCAde8 in OK130 under adenine selection with nuclear integration of unselected DNA were as high as $80 \%$ of clones. Co-transformation rates of expressed genes reached $26-42 \%$ for various laccase genes and up to $67 \%$ with $/ c c 9$ silencing vectors. The bacterial gene $h p h$ can also be used as another, albeit less efficient, selection marker for OK130 transformants, but with similarly high co-transformation rates. We further show that the pab1-1 defect in AmutBmut is due to a missense mutation which changed the conserved PIKGT motif for chorismate binding in the C-terminal PabB domain to PIEGT in the mutated 4-amino-4-deoxychorismate synthase.

Conclusions: ade8-1 and pab1-1 auxotrophic defects in C. cinerea reference strains OK130 and AmutBmut for complementation in transformation are described. pCcAde8 is a new transformation vector useful for selection in single and co-transformations of the sequenced monokaryon OK130 which was transformed for the first time. The bacterial gene $h p h$ can also be used as an additional selection marker in OK130, making in combination with ade $8^{+}$successive rounds of transformation possible.
\end{abstract}

\footnotetext{
*Correspondence: ukuees@gwdg.de

${ }^{1}$ Molecular Wood Biotechnology and Technical Mycology,

Büsgen-Institute, University of Goettingen, Büsgenweg 2,

37077 Goettingen, Germany

Full list of author information is available at the end of the article
}

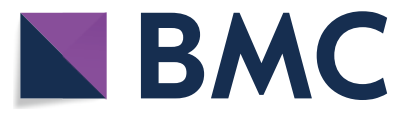

(c) The Author(s) 2020. This article is licensed under a Creative Commons Attribution 4.0 International License, which permits use, sharing, adaptation, distribution and reproduction in any medium or format, as long as you give appropriate credit to the original author(s) and the source, provide a link to the Creative Commons licence, and indicate if changes were made. The images or other third party material in this article are included in the article's Creative Commons licence, unless indicated otherwise in a credit line to the material. If material is not included in the article's Creative Commons licence and your intended use is not permitted by statutory regulation or exceeds the permitted use, you will need to obtain permission directly from the copyright holder. To view a copy of this licence, visit http://creativeco mmons.org/licenses/by/4.0/. The Creative Commons Public Domain Dedication waiver (http://creativecommons.org/publicdomain/ zero/1.0/) applies to the data made available in this article, unless otherwise stated in a credit line to the data. 
Keywords: Adenine auxotrophy, De novo purine biosynthesis, Transformation vector, Para-aminobenzoic acidauxotrophy, Tryptophan auxotrophy, Hygromycin B resistance, Basidiomycete

\section{Background}

Coprinopsis cinerea is a well-known model fungus for studying biological processes in Agaricomycetes. As early as in 1987 and for one of the first fungi of all, protoplast transformation of C. cinerea was successfully established by Binninger et al. [1]. For DNA transformation, protoplasts are usually generated from easy to regenerate single-celled haploid aerial mitotic spores (oidia) and are commonly treated in PEG $4000 / \mathrm{CaCl}_{2}$-mediated coldshock transformation with ca. $1 \mu \mathrm{g}$ plasmid DNA. The protocol is highly efficient with in best cases up to several hundreds of transformants per $\mu$ g DNA [1-4]. Up till today, the protoplasting and transformation protocol of Binninger et al. [1] has not much been changed in the principles. However, the method was later more simplified and specified in details as compared to the original description [2, 3]. Comprehensive troubleshooting tips have been provided to identify and correct possible subconscious while crucial small handling errors in order to ensure reliable transformation [4].

One reason for the very high transformation rates of C. cinerea is that mostly homologous selection markers are used for the complementation of auxotrophies. The bifunctional tryptophan synthase gene $\operatorname{trp} 1^{+}$cloned in the pUC9-based $9.8 \mathrm{~kb}$-sized plasmid pCc1001 [1] is so far most often applied in transformation. More recently, the shorter pBluescript $\mathrm{KS}^{-}$-based $\operatorname{trp} 1^{+}$-plasmid pBD5 (7 kb) with higher copy number in Escherichia coli and the $\operatorname{trp} 1^{+}$yeast-shuttle vector pYtrp1 $(9.9 \mathrm{~kb})$ have been established [5]. The two gene halves of $\operatorname{trp} 1^{+}$, i.e. $\operatorname{trp} A^{+}$ for the Trp1 A domain responsible for the aldo-cleavage of indole-3-glycerol-phosphate (IGP) into indole and $\operatorname{trp} B^{+}$for the Trp1 B domain for the subsequent pyridoxal phosphate cofactor-dependent conversion of indole with serine to tryptophan [5], have been functionally separated into individual yeast-shuttle vectors pYAdom $(8.3 \mathrm{~kb})$ and pYBdom $(8.7 \mathrm{~kb})$ to allow successive rounds of transformation into $C$. cinerea trp1.1,1.6 double mutant strains with first $\operatorname{trp} 1.6(\operatorname{trp} B)$ and then $\operatorname{trp} 1.1$ $(\operatorname{trp} A)$ complementation [6].

Two other genes from the tryptophan biosynthesis pathway cloned in vectors for transformation of suitable C. cinerea mutant strains are $\operatorname{trp} 2^{+}$[2] for a trifunctional enzyme with glutamine amidotransferase (GATase; anthranilate synthase component II which releases ammonia from glutamine), phosphoribosylanthranilate isomerase (PRAI) and indol-3-glycerol-phosphate synthase (IGPS) activities [5], and the gene $\operatorname{trp} 3^{+}[7,8]$ for anthranilate synthase component I which uses ammonia and chorismate to produce anthranilate, 2-aminobenzoic acid [5]. Cloned is also a positively selectable mutant gene $\operatorname{trp} 3^{\text {iar }}$ for a dominant 5-fluoroindole-resistant anthranilate synthase component I mutant [9]. $p a b 1^{+}$ vectors $[3,10]$ have been provided for complementation of auxotrophies in para-aminobenzoic acid (PABA) synthesis caused by defects in the bifunctional enzyme Pab1. Conventionally, this fungal enzyme is known as PABA synthase but more precisely, it is a 4-amino-4-deoxychorismate (ADC) synthase. The enzyme consists of an N-terminal PabA domain (37\% identity, 53\% similarity to E. coli PabA; Fig. 1a) and a C-terminal PabB domain (30\% identity, 49\% similarity to E. coli PabB; Fig. 1a). PabA presents PABA synthase component II (or better called ADC synthase component II) and has a PabBdependent GATase function. The PabB domain as PABA synthase component I (or more precisely ADC synthase component I) will aminate chorismate in order to yield $\mathrm{ADC}$ as the direct precursor of PABA to be formed by an ADC lyase (PabC) $[11,12]$. Regarding further functional C. cinerea selection markers, a cosmid is mentioned in a conference proceeding that could complement an uncharacterized ades defect of $C$. cinerea in transformation [13].

Selection for dominant resistances is another strategy to obtain transformants. A carboxin resistance selection marker $\left(s d i 1^{R}\right)$ has been generated by site-specific mutation of the native C. cinerea sdil gene for the ironsulphur protein subunit (subunit $\mathrm{SdhB}$ ) of the mitochondrial succinate dehydrogenase (SDH) complex [14]. Flutolanil and carboxin resistance is moreover mediated through a spontaneous point mutation by an allele of the $s d h C$ gene for the $\mathrm{SdhC}$ cytochrome $b_{560}$ subunit of the SDH complex [15]. The $s d i 1^{R}$ allele has been cloned behind the heterologous constitutive gpdII promoter of Agaricus bisporus [14] which is highly active in C. cinerea [16]. Transformation rates of such optimized $s d i 1^{R}$ vectors were then high with $>100$ transformants $/ \mu$ g plasmid DNA [14]. Transformation rates with the $s d h C$ mutant allele under natural regulatory sequences in contrast were low with 1.0 to 4.8 transformants $/ 10^{5}$ viable protoplasts [15].

As functional bacterial resistance genes in C. cinerea, vectors with the $E$. coli hygromycin B phospotransferase gene $h p h[14,17]$ and the Streptoalloteichus hindustanus gene ble for a phleomycin binding protein are available [14]. Insertion of a functional intron after the second 
codon of the ble gene was essential for successful expression of the gene in $C$. cinerea behind the $A$. bisporus gpdII promoter [14]. Regarding expression of $h p h$, presence of an intron was not crucial. However, the entire coding region of $h p h$ is required to be inserted behind an active promoter in $C$. cinerea (native tub1 promoter or heterologous $A$. bisporus gpdII promoter) [14, 17]. The best-known $h p h$-vector pAN7-1 from transformation in filamentous ascomycetes for example lacks the first two codons for two lysine residues and by this reason did not function in C. cinerea transformation [14] unlike, although at low frequency ( 1 to 5 transformants/ $\mu \mathrm{g}$ plasmid DNA), in the basidiomycetes Hebeloma cylindrosporium [18] and Crinipellis perniciosa [19].

The obvious advantage of usage of dominant resistance markers for selection is that transformation becomes independent of any auxotrophies that are needed to be generated. Though, using dominant resistance markers for $C$. cinerea somewhat complicates the transformation procedure. Protoplasts are spread onto regeneration agar but for suppression of unwanted background growth, it requires an extra regeneration agar overlay with antibiotics for selection for positive transformants to grow through this overlay $[14,16]$. Handling of complementation of auxotrophies in transformation in contrast is much easier by just plating and then incubating protoplasts on regeneration agar [2-4]. However, through complementation of available auxotrophies and selections for dominant resistance markers, extra rounds of successive transformations in a same background become possible. Such makes strains more versatile for repeated genetic manipulations.

So far, the genomes of two distinct $C$. cinerea strains, the monokaryon Okayama 7/\#130 (short OK130) and the self-fertile homokaryon AmutBmut, have been sequenced by the Broad Institute (Boston, MA) and the JGI (Joint Genome Institute, Walnut Creek, CA), respectively [20,21]. AmutBmut carries a pab1-1 mutation and is easily be transformed by $p a b 1^{+}$vectors, a feature which is very useful in studying dikaryon-specific growth behavior and fruiting body development in this self-fertile strain, independently of a second genome [22-24]. On the other hand, to the best of our knowledge, strain OK130 with the first $C$. cinerea reference genome established had not yet been transformed before. This reference monokaryon carries an ade8-1 mutation [8] which we used here in transformation for selection by complementation. Missense mutations in the defective alleles pab1-1 and ade8-1 were identified in this study. In addition, transformants of OK130 were obtained with the dominant bacterial hygromycin resistance selection marker $h p h$.

\section{Results and discussion}

\section{Genes pab1 and ade8 in C. cinerea}

Classical mapping of $C$. cinerea localized gene pab1 $0.5 \mathrm{cM}$ upstream and gene ade $81.3 \mathrm{cM}$ downstream to the bipartite $A$ mating type locus (consisting of $A \alpha$ and $A \beta$ ) on linkage group I [25, 26]. The ca. $20 \mathrm{~kb}$-long $A 43$ mating type allele with all its homeodomain transcription factor genes locates at position Chr_1:2,666,138$2,647,809$ in the sequenced OK130 genome [20,27].pab1 [11] is found at location Chr_1:2,699,078-2,701,362, $32.94 \mathrm{~kb}$ apart from the $3^{\prime}$ end of the closest $A 43 \alpha$ gene a1-1 [20, 27]. $p a b 1^{+}$in OK130 (Broad model CC1G_01849T0) distinguishes from the pab1-1 allele in AmutBmut (JGI ID 414607) by a point mutation in codon 546, with a change from AAG to GAG. This missense mutation resulted in a K546E exchange in the PabB domain within the highly conserved ADC synthase component I motif PIKGT. Lysine in the wildtype (wt) covalently binds to the $\mathrm{C}_{2}$ of chorismate to initiate with the ammonia-group of glutamine the enzymatic formation of $\operatorname{ADC}([28-31]$, Fig. 1a).

\footnotetext{
Fig. 1 Alignment of A. wt Pab1 from C. cinerea monokaryon OK130 (CCPab1) with PabA (ECPabA, underlaid in yellow) and PabB of E. coli (EcPabB, underlaid in dusky pink) and B. wt Ade8 from C. cinerea strain AmutBmut (CCAde8) with PurD (ECPurD, underlaid in yellow) and PurM of E. coli (EcPurM, underlaid in dusky pink), respectively. a The catalytic triad, glutamine binding residues and residues involved in ammonia tunnel formation in PabA are marked with red, green and blue symbols *, respectively. Other residues affecting enzymatic activities and bonding to PabB are marked with grey squares. The position of a stabilizing residue stretch called oxyanion hole is underlaid in light blue, a sequence stretch for chorismate signal transfer in olive $[29,30,75]$. Red letters in PabB mark helical regions, blue letters $\beta$-sheets. The conserved PIKGT motif, sequences for interaction with PabA, for signal transfer of chorismate binding, and of a binding pocket for tryptophan implicated in structural stabilization are underlaid in olive, bright yellow, grey and light blue, respectively. The residue K in the PIKGT motif which is mutated in C. cinerea AmutBmut (K546E) is marked in red. Symbols * in red and black mark (predicted) active site residues and $\mathrm{Mg}^{2+}$-binding residues in two chorismate-interacting helices, respectively. Triangles in black indicate residues that contact the bound tryptophan and grey squares further residues where mutations affect functionality [28-31, 76]. b Red, blue, green and magenta letters mark the N, B, A, and C domains of PurD. The positions of the P-loop and the flexible A and B loops in PurD [56] are underlaid in light blue, olive and orange, respectively. Symbols * in black, red, and blue mark residues that recognize the adenine base, ribose and phosphate of the nucleotide, whereas grey squares indicate residues interacting with the ligand PRA $[56,57]$. The residue $N$ in the A loop which is mutated in C. cinerea OK130 (N231D) is marked in red. In PurM, symbols * mark (predicted) nucleotide binding residues and triangles (in grey predicted) binding sites of the substrate $N$-formylglycinamidine ribonucleotide (FGAM) [58]
} 
a

\begin{tabular}{|c|c|c|c|}
\hline$F \bar{c}$ & & $\begin{array}{l}\text { PILLVDSYDSFTHNLAA-LCRRSI } \\
\text { ILL+D+YDSFT NL C }\end{array}$ & \\
\hline$C \mathrm{PabA}$ & 1 & MILLIDNYDSFTWNLYQYFCELG---ADVLVKRNDALTLADIDALKPQ-----KIVIS & 0 \\
\hline $\mathrm{CPab}$ & 64 & $\begin{array}{l}\text { PGPGSPSKPEDIGIVRDLWKLDSEHVLPIFGVCLGLQSLVLEFGGELKRLHTVKHGQISK } \\
\text { PGP }+\mathrm{P}++\mathrm{GI} \mathrm{D}++++ \text { LPI GVCLG }++\frac{\text { FGG }++\mathrm{R}}{\mathrm{V}} \mathrm{HG}+\mathrm{S}\end{array}$ & 20 \\
\hline CPabA & 51 & 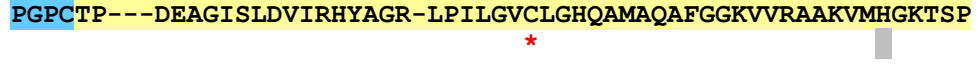 & 6 \\
\hline$C \mathrm{Pab} 1$ & 121 & $\begin{array}{l}\text { VEHVPSEIFQDVGE-IHAVRYHSLHV---ALPSDGSVEELAWVDEEENGHVVMAVKHTRL } \\
+\mathrm{H}+\mathrm{F}+++\mathrm{RYHSL} \mathrm{V}+\mathrm{LP}++\mathrm{AW}+\mathrm{E}+\mathrm{M}++\mathrm{H}+\end{array}$ & 76 \\
\hline$C \mathrm{PabA}$ & 107 & $\begin{array}{l}\text { ITHNGEGVFRGLANPLTVTRYHSLVVE PDSLPA--CFDVTAWSETRE----IMGIRHRQW } \\
\qquad \star \star \star \star\end{array}$ & 50 \\
\hline CPab1 & 77 & $\begin{array}{l}\text { PFWAVQYHPESVRTEGGGWKVLSNFWTLCQEWSKNNGRAPTPWNPS IQNEVGALWPYNHS } \\
\text { VQ +HPES }++E G++\mathrm{L} \text { G }\end{array}$ & 36 \\
\hline B & $161 / 1$ & $\begin{array}{l}\text { DLEGVQFHPESILSE-QGHQLLANFLHR } \\
\star \star \star\end{array}$ & 87 \\
\hline CPabl 1 & 237 & 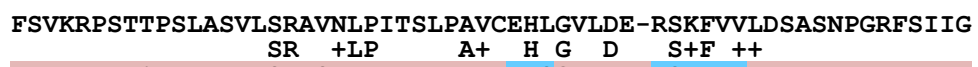 & 5 \\
\hline $\mathrm{CPabB}$ & 7 & AVITLLWRQDAAEFYFSRLSHLPW----AMLLHSGYADHPYSRFDIV------------ & 19 \\
\hline$C \mathrm{Pab} 1$ & 296 & 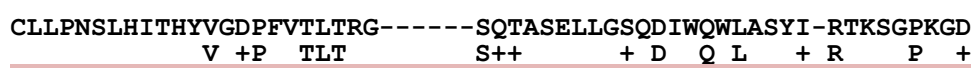 & 48 \\
\hline$C \mathrm{P}$ & 50 & -----------VAEPICTLTTFGKETVVSESEKRTTTTDDPLQVLQQVLDRADIRPTHN & 7 \\
\hline CPab1 & 49 & 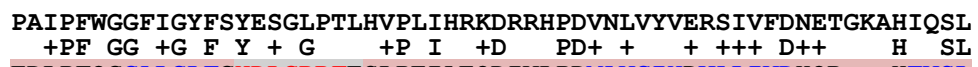 & \\
\hline$c \mathrm{~Pa}$ & 98 & EDLPFQGGALGLFGYDLGRRFESLPEIAEQDIVLPDMAVGIYDW. & \\
\hline $\mathrm{PP}$ & 409 & 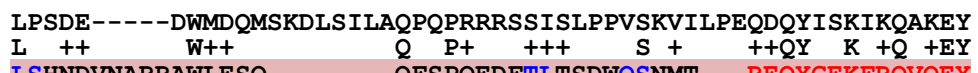 & \\
\hline $\mathrm{P}$ & 55 & LSHNDVNARRAWLESQ--------Q̄FS PQEDFTLTSDWQSNMT---REQ̄YGEKFRQ̈VQEY & \\
\hline $\mathrm{P}$ & 204 & $\begin{array}{l}\text { LYSGDSYELCLTAQTKILIPHQQSKGSTTSTSWERYLRLREKNPAPHSAYIRLHPTTLMS } \\
\mathrm{L} \text { GD Y }++\mathrm{L} \\
\mathrm{L}\end{array}$ & \\
\hline$E_{C P}$ & 204 & LHSGDCYQVNLA--------QRFHATYSGDEWQAFLQLNQANRAPFSAFLRLEQGAILS & \\
\hline CCPab1 & 24 & $\begin{array}{l}\text { SSPERFLSYSRPPHSVCQLRPIKGTVRKGPGITREVATQL-LAGSPKEV } \\
\text { SPE RF }+\mathrm{S} Q \mathrm{RPIKGT}+\mathrm{P}+\mathrm{t} \text { LA S Kt }\end{array}$ & \\
\hline $\mathrm{P}$ & 55 & $\begin{array}{l}\text { PERFILCD---NSEIQTRPIKGTLPRLPDPQEDSKQAVKLANSAKDRAENLMIVDLMR } \\
\text { * }\end{array}$ & \\
\hline$P a$ & 93 & $\begin{array}{l}\text { LHGV-VGDNVVVSKFCGVEEYETVWQLVSVIEGKEDPSVSVEEEL-GWNV } \\
+\mathrm{V} \mathrm{V}+\mathrm{V} \mathrm{V}+\mathrm{VE}+\mathrm{V} \text { LVS I }+\mathrm{E}+\mathrm{L}++\end{array}$ & \\
\hline$E_{C P}$ & 312 & GRVAVAGSVKVPELFVVEPFPAVHHLVSTI-- & 365 \\
\hline $\mathrm{CCP}$ & 651 & 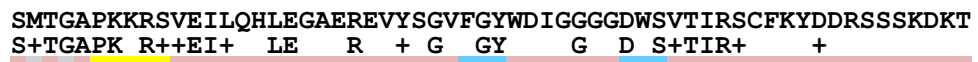 & \\
\hline$E_{C P}$ & 366 & $\begin{array}{l}\text { SITGAPKVRAMEIIDELEPQRRNAWCGSIGYLSFCGNMDTSITIRTLTAING-------- } \\
\text { * }\end{array}$ & 11 \\
\hline $\mathrm{CCPa}$ & 701 & $\begin{array}{l}\text { EEWAIGAGGAITALSDPDAEWDEMEVKLQSVLKSFGCHITNFVNGGEAEAPL } \\
+\quad \mathrm{AGG} \text { I A S +AE+ E K+ } \mathrm{LK}\end{array}$ & \\
\hline$\uplus_{C P}$ & 41 & -QIFCSAGGGIVADSQEEAEYQETFDKVNRILKQLEK & \\
\hline
\end{tabular}




\begin{tabular}{|c|c|c|c|}
\hline cAde 8 & Ms & 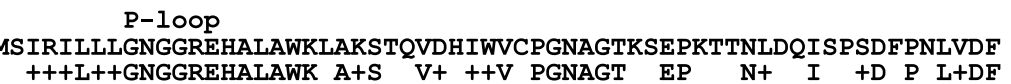 & 62 \\
\hline PurD & 1 & MKVLVIGNGGREHALAWKAAQSPLVETVFVAPGNAGTTLEPALQNV-AIGVTDIPALLDF & 59 \\
\hline Ade 8 & 63 & $\begin{array}{l}\text { AVKNNVSLVVPGPEQPLVDGVESHFRKVGIPVFGPSEKAARMEGSKAFSKDFMARHNIPT } \\
\text { A V L }+ \text { GPE PLV GV FR G+ }+ \text { FGP }+ \text { AA++EGSKAF+KDF+ARHNIPT }\end{array}$ & 122 \\
\hline PurD & 60 & AQNEKVDLTIVGPEAPLVKGVVDTFRAAGLKIFGPTAGAAQLEGSKAFTKDFLARHNIPT & 119 \\
\hline Ade 8 & 123 & $\begin{array}{l}\text { B-loOp } \\
\text { AQFRVFKAPELDAAINYINTCGHSVVLKASGLAAGKGVLIPETKEEAIAGLKEILVDGVF } \\
\text { A++ F E++ A+ Y+ G +V+KA GLAAGKGV }++ \text { T EEA A }++++\mathrm{L} \text { F }\end{array}$ & 182 \\
\hline$c$ PurD & 120 & $\begin{array}{l}\text { AEYQNFT--EVEPALAYLREKGAPIVIKADGLAAGKGVIVAMTLEEAEAAVRDMLAGNAF } \\
\star\end{array}$ & 177 \\
\hline CAde 8 & 183 & $\begin{array}{l}\text { GDAGNEVVIEELLTGPEISVLAICDGYTIIPLPAAQDHKRIGEGDTGLNTGGMGAYAPAP } \\
\text { GDAG+ +VIEE L G E }++ \text { DG ++P+ +QDHKR+G }+ \text { DTG NTGGMGAY+PAP }\end{array}$ & 242 \\
\hline PurD & 178 & $\begin{array}{l}\text { GDAGHRIVIEEFLDGEEASFIVMVDGEHVLPMATSÕDHRVDKDTGPNTGGMAYSPAP } \\
\qquad \star \star \star *\end{array}$ & 237 \\
\hline Ade 8 & 243 & $\begin{array}{l}\text { VATPEIMERIMNETLKPTIDGMRREGYPFVGVLFTGFMLTDSG-PKVLEYNVRFGDPETE } \\
\text { V T E + }+\mathrm{M}+\mathrm{PT}+\mathrm{GM} \text { EG }+\mathrm{G} \text { L+TG M+ G PKV+E+N RFGDPET+ }\end{array}$ & 301 \\
\hline CPurD & 238 & $\begin{array}{l}\text { VVTDEVHQRTMERI IWPTVKGMAAEGNTYTGFLYTGLMIDKQGNPKVIEFNCRFGDPETQ } \\
\star \star\end{array}$ & 297 \\
\hline Ade 8 & 302 & $\begin{array}{l}\text { ALMLLLKKDVDLASVFLAAAERRLDSVQVEFQEGVAVTVILASQGYPGSYPKGKVIAIGD } \\
+\mathrm{ML}+\mathrm{K} \mathrm{L}+\mathrm{LAA} \mathrm{E}+\mathrm{LD} \mathrm{E}+\mathrm{E}++\mathrm{V}++\mathrm{A}+\mathrm{GYPG} \mathrm{Y} G \mathrm{VI}\end{array}$ & 361 \\
\hline CPurD & 298 & PIMLRMKSD--LVELCLAACEGKLDEKTSEWDERASLGVVMAAGGYPGDYRTGDVIH--G & 353 \\
\hline Ade 8 & 362 & $\begin{array}{l}\text { LP---- SDVVVFHAGTKYSGND-IVTSGGRVLAVTAYGHTIQEALASAYKAVDNVSFDGK } \\
\text { LP +D VFHAGTK }++++ \text { VTSGGRVI VTA GHT }+ \text { EA AY }++++D\end{array}$ & 416 \\
\hline EcPurD & 354 & LPLEEVADGKVFHAGTKLADDEQVVTSGGRVLCVTALGHTVAEAQKRAYALMTDIHWDDC & 413 \\
\hline & 417 & $\begin{array}{l}\text { TYRRDIAHRAL-KDQ--PASTGLTYAQAGVSVDAGNALVEAIKPFVKATRRPGADADIGG } \\
\text { R+DI RA }++Q+\mathrm{T} L+\mathrm{Y} \text { AGV +DAGNALV IK VK TRRP +G }\end{array}$ & 473 \\
\hline PurD/M & $414 / 1$ & $\begin{array}{l}\text { FCRKDIGWRAIEREQNMTDKTSLSYKDAGVDIDAGNALVGRIKGVVKKTRRPEVMGGLGG } \\
\text { * }\end{array}$ & $429 / 44$ \\
\hline Ade 8 & 474 & $\begin{array}{l}\text { FGGVFDLKATGFKDPVLVSGTDGVGTKLRLAVDCDIHDTVGIDLVAMSVNDLLVQGAEPL } \\
\text { FG }+\mathrm{L}+++ \text { PVLVSGTDGVGTKLRLA+D HDT+GIDLVAM VNDL+VQGAEPL }\end{array}$ & 533 \\
\hline ECPurM & 45 & $\begin{array}{l}\text { FGALCALPQK-YREPVLVSGTDGVGTKLRLAMDLKRHDTIGIDLVAMCVNDLVVQGAEPL } \\
\qquad \star \star \nabla \nabla \nabla\end{array}$ & 103 \\
\hline Ade 8 & 534 & $\begin{array}{l}\text { YFLDYYGCSKLDVPVATQVVKGIAEGCRQAGCALIGGETAEMPGMYLPGDYDLAGFAVGA } \\
+ \text { +FLDYY KLDV A+ V+ GIAEGC Q+GC+L+GGETAEMPGMY DYD+AGF VG }\end{array}$ & 593 \\
\hline EcPurM & 104 & $\begin{array}{l}\text { FFLDYYATGKLDVDTASAVISGIAEGCLQ̃SGCSLVGGETAEMPGMYHGEDYDVAGFCVGV } \\
\forall \star \star\end{array}$ & 163 \\
\hline CCAde 8 & 594 & $\begin{array}{l}\text { VERDLILPTPNIVPGDVLIGLTSSGLHSNGFSLVRKI IQVSGLTYTSPCPWSPDV---PL } \\
\text { VE }+ \text { It }+ \text { GDVLI I SSG HSNG+SLVRKI }++ \text { SSG } \\
\text { P }+++\end{array}$ & 650 \\
\hline CPurM & 164 & $\begin{array}{l}\text { VEKSEIIDGSKVSDGDVLIALGSSGPHSNGYSLVRKILEVSGCD-----PQTTELDGKPL } \\
\qquad \nabla \nabla \nabla\end{array}$ & 218 \\
\hline CCAde 8 & 651 & 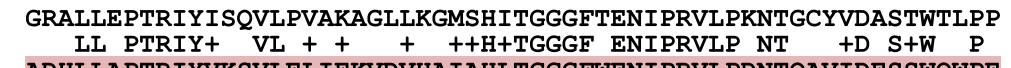 & 710 \\
\hline PurM & 219 & ADHLLAPTRIYVKSVLELIEKVDVHAIAHLTGGGFWENIPRVLPDNTQAVIDESSWQWPE & 278 \\
\hline CCAde 8 & 711 & 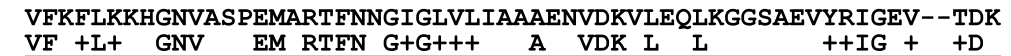 & 768 \\
\hline PurM & 279 & VFNWLQTAGNVEHHEMYRTFNCGVGMI IALPAPEVDKALALLNANGENAWKIGIIKASD- & 337 \\
\hline & 769 & $\begin{array}{l}\text { PGVEMRNLSAWD } \\
\text { E R }+\end{array}$ & \\
\hline urm & 338 & --SEQRVVIE & \\
\hline
\end{tabular}

Fig. 1 continued

The recombination rate between $p a b 1$ and $A \alpha$ calculates as $\geq 66 \mathrm{~kb} / \mathrm{cM}(\geq 70-75 \mathrm{~kb} / \mathrm{cM}$ with the whole $p a b 1$ gene sequence included $[8,32])$. Other studies estimated the average recombination frequency over the $C$. cinerea genome higher as $27.9 \mathrm{~kb} / \mathrm{cM}$ [33] and $33 \mathrm{~kb} / \mathrm{cM}$ [20], respectively. With the same $\mathrm{kb} / \mathrm{map}$ unit relations, ade8 should then locate about 40 to $100 \mathrm{~kb}$ downstream of $A \beta$. A gene for a bifunctional purine biosynthetic 
protein (CC1G_01782T0; Table 1) was found in the OK130 genome at location Chr_1:2,548,109-2,550,858, $97 \mathrm{~kb}$ downstream to the closest $A 43 \beta$ gene $d 1-1$ [20, 27], with a possible recombination rate of $74.6 \mathrm{~kb} / \mathrm{cM}$ using $1.3 \mathrm{cM}$ for calculation.

Many mutations leading to adenine-auxotrophies belong directly to the de novo purine biosynthesis pathway [34-36]. Other indirect mutations include defects in tetrahydrofolate (THF) cofactor formation, further folate metabolism and THF-mediated C1-metabolism, as well as defects in cross-pathway regulation of de novo purine biosynthesis and syntheses of amino acids (histidine, methionine) mediated by feedback control of certain metabolites [5'-phosphoribosyl-5-monophosphate (AICAR)] or shared transcriptional regulators [35, 3748]. We screened the OK130 genome for such genes, using known E. coli and Saccharomyces cerevisiae proteins in tblastn searches. Spread over 7 chromosomes, genes for all enzymatic functions for de novo purine biosynthesis and for other mentioned functions were found (Table 1). Previously, twelve different ade complementation groups have been described in $C$. cinerea, two more mutants that react to adenine and histidine ( $a d / h i s 1$ and $a d / h i s 2)$ and another that reacts alternatively to adenine or methionine (ad/met) $[49,50]$. Ten of these genes have been mapped onto 7 linkage groups [50-52]. Though, in our analysis only four to possibly seven genes (ade2, ade8, ade1, ade5, and possibly ade4, ade9, and ade12) from only four linkage groups could be assigned to specific positions on sequenced chromosomes (Table 1), using as additional information their clearly defined biochemical reactions (cases ade1, ade5 [49]) or approximate positions in the de novo purine biosynthesis pathway (ade2, ade3, ade4 and ade 8 all act prior to imidazole ring closure [49]) and/or their linkages (ade2, ade3, ade5, ade8, ade9 and ade12) to other unquestionably identifiable gene functions on the classical C. cinerea map ( [33, 50-52]; see footnote of Table 1). However, no other convincing candidate for gene ades were found in appropriate distance to the $A$ locus on chromosome 1 (Table 1 ).

The protein encoded by the gene at Chr_1:2,548,1092,550,858 has been annotated in GenBank (EAU92737.2) as ADE1 [Coprinopsis cinerea Okayama 7/\#130] which conflicts the traditional $C$. cinerea gene nomenclature. C. cinerea gene ade1 resides on linkage group IV of the fungus $[51,52]$ which corresponds to chromosome 5 in the OK130 genome assorted by chromosome sequence length ( [20], Table 1). Moreover, Ade1 of C. cinerea had been shown in the de novo purine biosynthesis to function in the 6th step directly after 5-aminoimidazole ribonucleotide (AIR) ring closure as phosphoribosylaminoimidazole carboxylase in the formation of 5-amino-4-imidazolecarboxamide ribonucleotide (CAIR) ( [49], Table 1).

The gene at location Chr_1:2,548,109-2,550,858 has homologs in other fungi that, by historical naming of adenine-auxotrophic mutants, are variably known as ade1 such as in Phanerochaete chrysosporium, ade5 in Schizophyllum commune, ade2 in Neurospora crassa, ade5,7 in S. cerevisiae and pur2, pur2,5 and pur2,7 in Yarrowia lipolytica, Ogataea angusta and Scheffersomyces stipitis, respectively (Fig. 2). Gene $a d e 5^{+}$of S. commune can complement ade1 defects of P. chrysosporium like the homologous native $a d e 1^{+}$gene and it can complement ade 2 defects of the ascomycete $N$. crassa [53, 54]. All mentioned fungal genes encode bifunctional enzymes for the de novo biosynthesis of purines, with an N-terminal glycinamide ribonucleotide synthase (GARS) domain and a C-terminal aminoimidazole ribonucleotide synthase (AIRS) domain (Fig. 1b; Table 1) which act in the 2 nd and the ring-closing 5th step in de novo purine biosynthesis, respectively [34-36]. ade5 of $S$. commune and ade8 of $C$. cinerea are conserved in chromosomal location relative to the position of $A \beta$, similar as their pab1 genes are relative to $A \alpha[8,32,55]$. The gene for a bifunctional GARS-AIRS enzyme identified here on C. cinerea chromosome I with good likelihood thus presents its ade8 gene.

The N-terminal halves of the fungal bifunctional GARS-AIRS enzymes correspond to bacterial PurD enzymes (49\% identity, $67 \%$ similarity between the $C$. cinerea enzyme and $E$. coli PurD; Fig. $1 \mathrm{~b}$ ) which are glycinamide ribonucleotide (GAR) synthases represented in structure e.g. by the crystalized E. coli PurD protein (1GSO_A). PurD catalyzes the 2nd step of the de novo purine biosynthetic pathway, the conversion of phosphoribosylamine (PRA), glycine, and ATP to GAR, ADP (adenosine diphosphate), and phosphate $(\mathrm{Pi})([35,56$, 57], Table 1). The C-terminal halves of the fungal bifunctional GARS-AIRS enzymes are homologous to bacterial PurM enzymes (55\% identity, 67\% similarity of the C. cinerea enzyme to E. coli PurM; Fig. 1b). PurM represented in structure by $E$. coli 1CLI_A is a phosphoribosylformylglycinamidine cyclo-ligase that catalyzes the conversion of formylglycinamide ribonucleotide (FGAM) and ATP to AIR, ADP, and Pi, in the 5th step in de novo purine biosynthesis ( $[35,58]$, Table 1$)$.

The folded bacterial GARSs consist of the three domains $\mathrm{N}, \mathrm{A}$, and $\mathrm{C}$ forming the central core of the enzyme and, connected to them by flexible hinges, the outward-extended domain B [56]. Substrate PRA is recognized by specific amino acids in the $\mathrm{N}, \mathrm{A}$, and $\mathrm{C}$ domains. The A domain further confers the binding site for the ligand glycine ( $[56,57]$, Fig. 1b). GARSs are members of the ATP-grasp superfamily of enzymes with an 


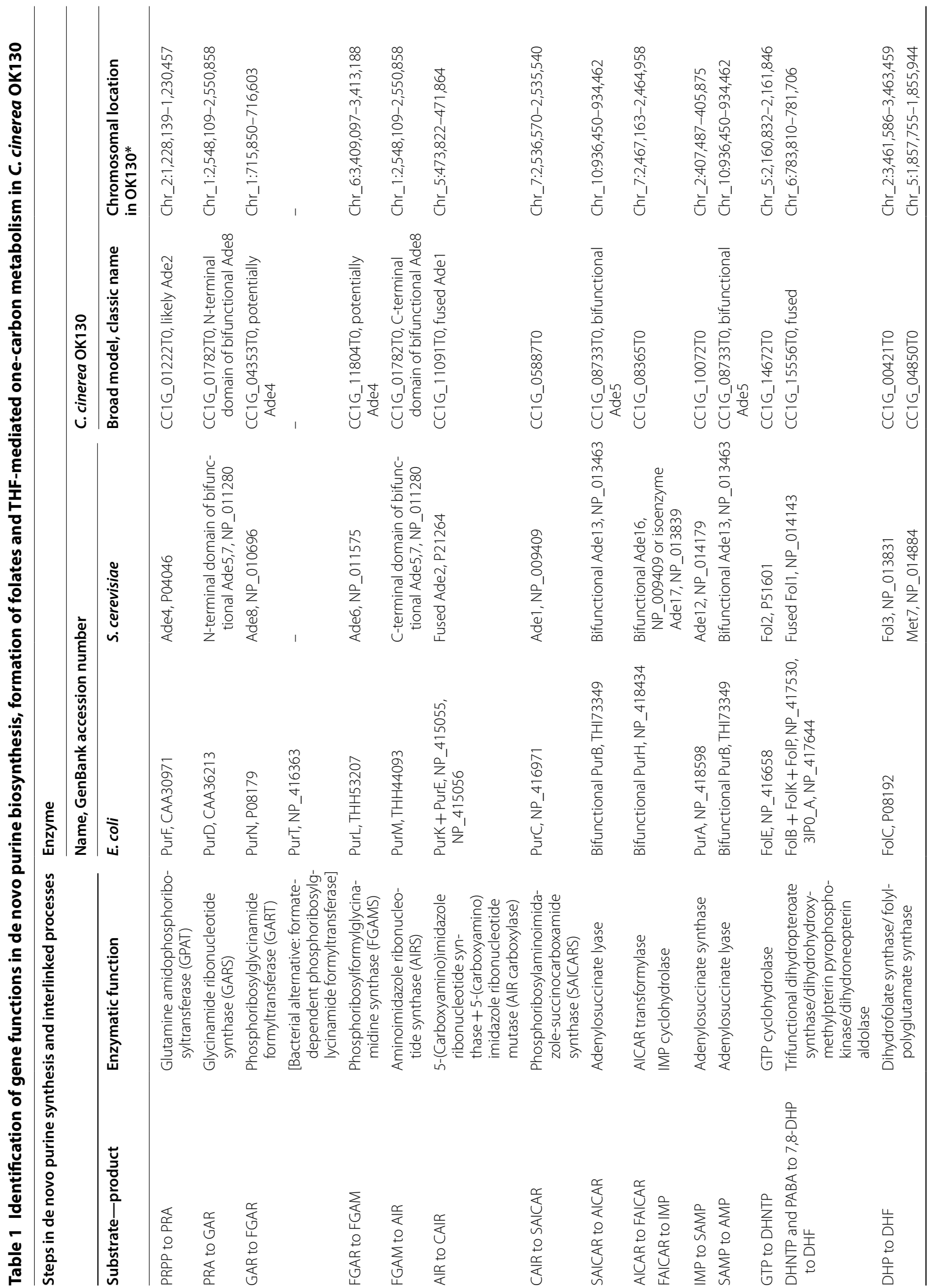




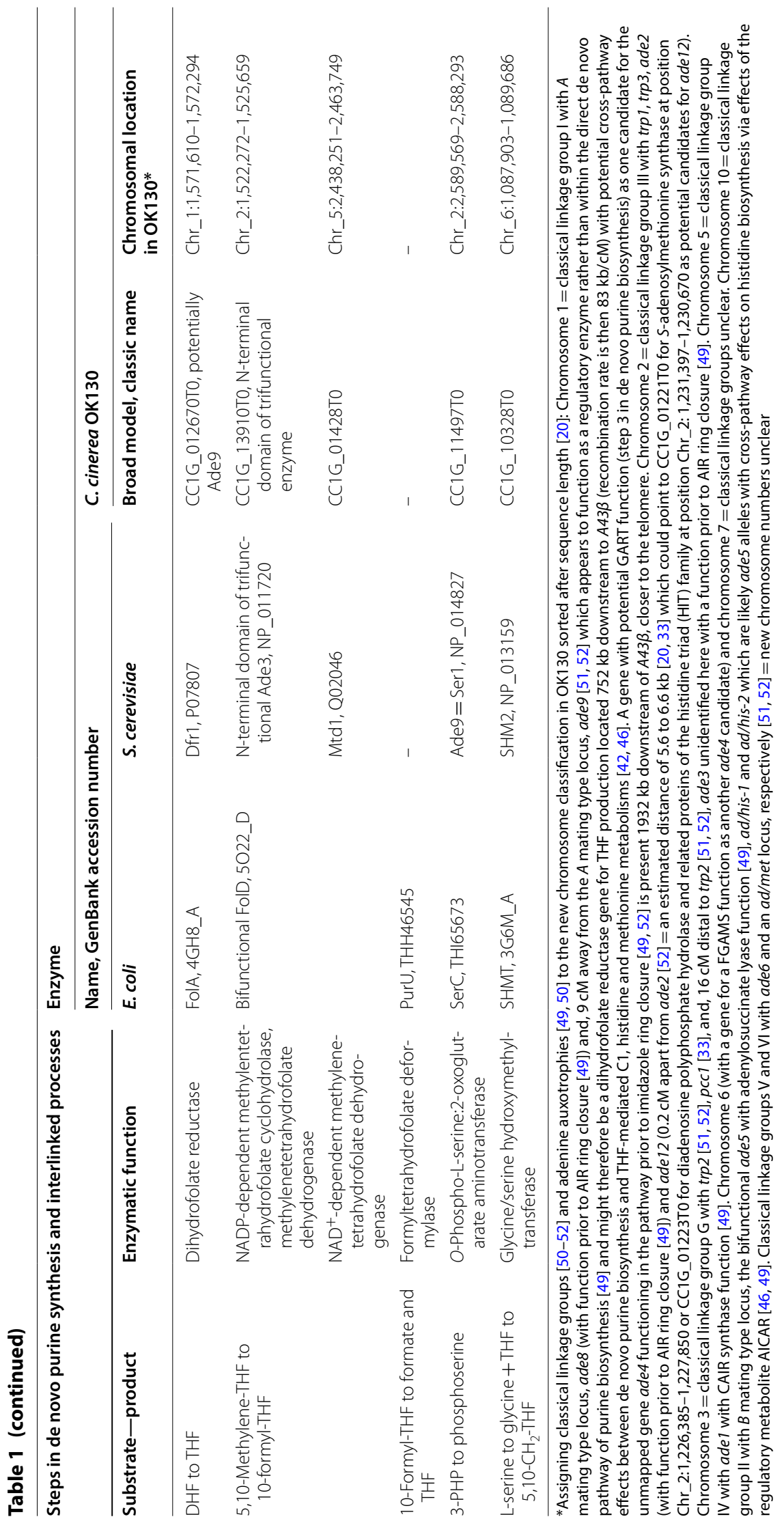




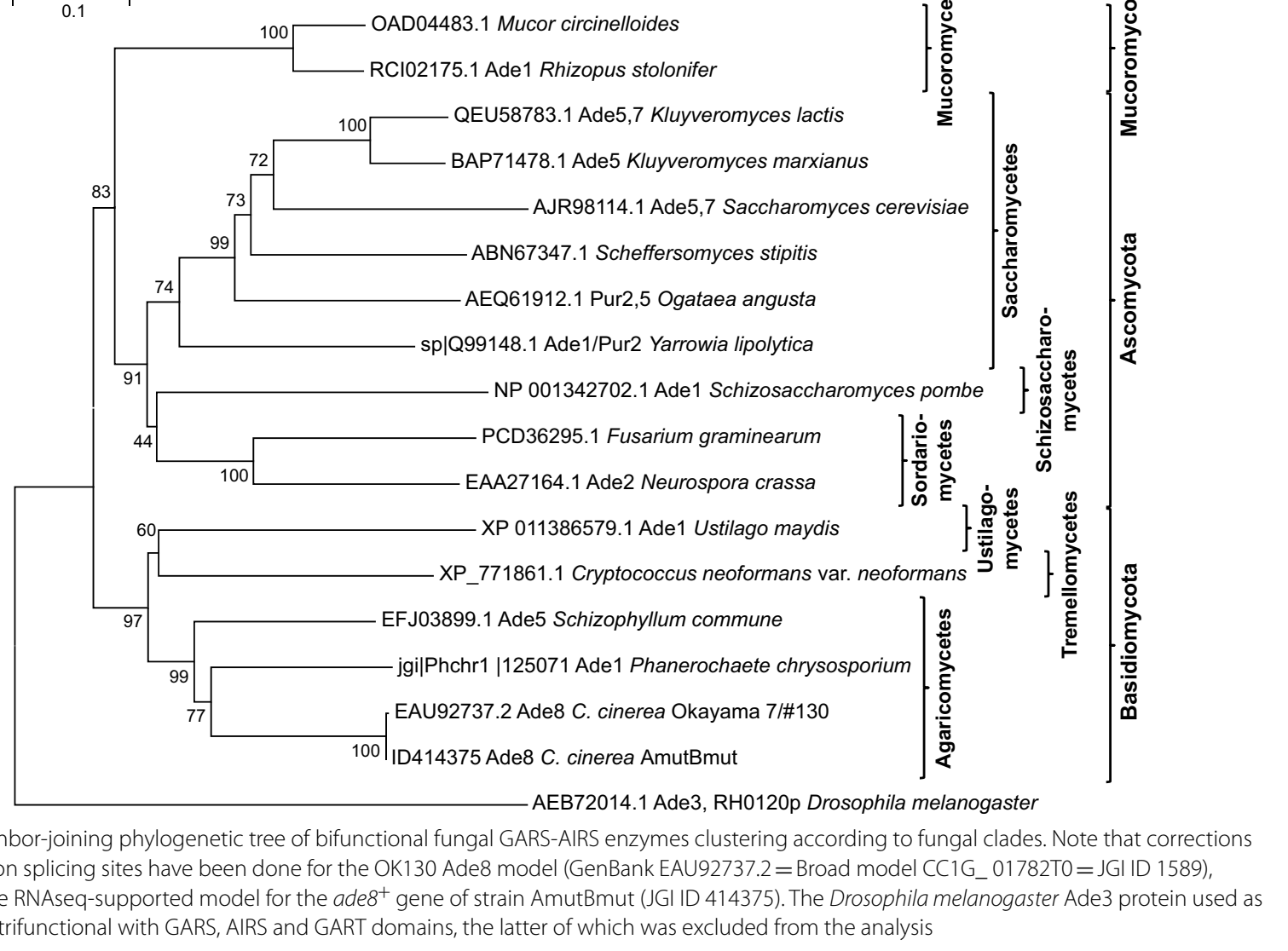

atypical ATP-binding site (ATP-grasp fold) comprised by the two domains A and B that catch an ATP between them [59]. Accordingly, the A and B domains primarily define the ATP/ADP binding site of GARSs, with distinct residues in domains $\mathrm{A}$ and $\mathrm{B}$ and also in $\mathrm{N}$ contacting the adenine base, ribose and phosphate, respectively ( $[56,57]$, please see Fig. $1 \mathrm{~b}$ for details). Further, the A domain possesses a flexible specific A loop with a highly conserved unique sequence (DHKRVGDKDTGPNTGGMG in E. coli, see Fig. 1b) which distinguishes GARSs well from all other members of the ATP-grasp superfamily $[56,57,59]$. Structural analyses of bacterial enzymes revealed $\mathrm{N} 226$ in the $E$. coli A loop to recognize ribose [57]. The $E$. coli A loop shares $83-89 \%$ sequence identity and $94 \%$ sequence similarity with the loops in the fungal enzymes analyzed in Fig. 2, with amino acid N231 of wt $C$. cinerea Ade $8=\mathrm{N} 226$ in PurD of E. coli (Fig. 1b). Sequence comparison between the functional ade ${ }^{+}$ copy from AmutBmut and the defective ade8-1 allele in OK130 revealed a point mutation that altered codon 231 from AAT into GAT and then, within the flexible A loop in the GARS A domain, the highly conserved amino acid N231 into D231 (Fig. 1b). The D231 mutation in the $\mathrm{N}$-terminal GARS half explains then the former observation that Ade 8 acts prior to imidazole ring formation [49] and, more specifically, assigns the loss of the Ade8 function in OK130 to the 2nd step of de novo purine biosynthesis.

\section{The $\mathrm{pCcAde} 8$ vector in fungal transformations}

The wt genomic sequence with the $a d e 8^{+}$coding region (with 9 exons and 8 introns) and 483 and 569 bp upstream and downstream, respectively were PCR-amplified with chimeric primers Ade8f and Ade8r in order to construct vector $\mathrm{pCc}$ Ade8 (Fig. 3) by in vivo recombination in yeast with plasmid pRS426 [60]. pCcAde8 was transformed into monokaryon OK130, alone and, using protoplasts from same batches, in parallel co-transformations with other vectors (Table 2). Adenine prototrophic transformants were selected by growth on adenine-free regeneration agar. Diagnosis PCR with amplicon sequencing verified for 25 transformants randomly chosen from group pCcAde $8+$ pYSK- $l c c 5$ (experiment 1 in Table 2, 
1st to 4th day of collection) in all cases the presence and function of the $a d e 8^{+}$allele.

Transformation rates of OK130 to ade $8^{+}$prototrophy in single-plasmid and two-plasmid transformations were in ranges of about 40 to 60 clones each (Table 2). Gene ade $8^{+}$therefore might not confer any significant feedback inhibition on the de novo purine biosynthesis pathway in C. cinerea. On the contrary, the $\operatorname{trp} 1^{+}$selection marker of $C$. cinerea can cause suicidal feedback inhibition on tryptophan biosynthesis with loss of affected clones by a sudden overflow of the amino acid from more expressed $\operatorname{trp} 1^{+}$copies $[5,6]$. This adverse effect on clone viabilities is greater with the single-plasmid transformation than when using mixtures of two plasmids, because singular plasmids in transformation without competition are likely to integrate into twice as many spontaneous DNA breaks per nucleus $[5,6]$. As in our previous work with trp1.1,1.6 monokaryons [5, 6], reduced amounts of tryptophan prototrophs were obtained in only $\operatorname{trp} 1^{+}$-vector pDB5 transformations of strains FA2222 and PG78 as compared to any co-transformations (Tables 3 and 4). pCcAde8 was newly tested in such co-transformations. Numbers of total transformants under $\operatorname{trp} 1^{+}$selection were about 1.5-2.5 times higher in the co-transformations with $\mathrm{pCcAde} 8$ than in the single-vector transformation, similar to results of co-transformations with other plasmids (Tables 3 and 4). In co-transformations of monokaryon PG78 with $p a b 1^{+}$-vector pPAB1-2 for selection for PABA-prototrophy, total transformation rates were slightly higher with $\mathrm{pCcAde} 8(1.9 \times$ and $1.3 \mathrm{x})$ as compared to other plasmids and in single-plasmid transformation (Table 4). PABA is an intermediate in the biosynthesis of folate [61] which in turn is required in steps of de novo purine biosynthesis for the cofactor THF (Table 1). Co-transforming $\mathrm{pab1}^{+}$-vector pPAB1-2 with $\mathrm{p} C c$ Ade8 might have an initial promoting effect on protoplast regeneration and clone numbers. Typically in transformations of $C$. cinerea with selection schemes other than adenine, we add adenine sulfate as optional supplement to regeneration agar (50 or $100 \mathrm{mg} / \mathrm{l}$ ) [3, 4] because this can stimulate protoplast regeneration [advice by late L.A. Casselton kindly given to UK].

Co-transformation of a selectable vector together with one or more other plasmids is an efficient means to introduce and find non-selectable genes in transformed $C$. cinerea clones [62]. Because we have a deeper interest in laccase functions and applications [16, 63-68], several vectors used here in co-transformations contained either C. cinerea laccase genes for enzyme overexpression or were antisense constructs designed for laccase gene silencing (Tables 2 and 3). Most C. cinerea monokaryons in fungal cultures have some background laccase activities through expression of Lcc1 and Lcc5 and possibly other enzymes, with the exception of the laccase-free strain FA2222 [16, 64, 65]. Co-transformation to laccase production in monokaryon FA2222 can therefore phenotypically be easily followed up on regeneration agar by enzymatic conversion of the colorless $2,2^{\prime}$-azino-bis (3-ethylbenzothazoline-6-sulfonic acid) (ABTS) into a blue-greenish product seen as well-stained halos around growing clones [16]. Accordingly, co-transformation rates of strain FA2222 with $l c c 1$ expression vector pYSK7 in this study were $34 \%$ and $35 \%$, respectively (Table 3 ) and were in the range of ratios (25 to $43 \%$ ) obtained in other C. cinerea co-transformation experiments $[5,6$, 16]. Each 20 clones were randomly selected for liquid fermentations from the pBD5 and the pBD5+pYSK7 transformations, respectively. All selected pBD5 transformants showed no enzymatic activity whereas enzymatic activities for the staining pBD5 + pYSK7 transformants were between $0.3 \mathrm{U} / \mathrm{mL}$ and $3.4 \mathrm{U} / \mathrm{ml}$.

Monokaryon OK130 typically expresses in cultures some laccase Lcc1 and Lcc5, and traces of Lcc9 [65] why all typical transformants of only pCcAde 8 had faintly stained slender halos around their colonies on medium with ABTS whereas laccase-overexpressing transformants in contrast produced intense broad halos (Table 2; Fig. 4). Co-transformation rates of monokaryon OK130 of selection vector $\mathrm{pC} c \mathrm{Ade} 8$ with three different laccase overexpression constructs were similar like in the FA2222 co-transformations described above. Co-transformations of monokaryon OK130 led in $26 \%$ to $42 \%$ of all clones to phenotypically increased enzyme activities, from background laccase activities in OK130 and pCcAde8 control transformants of around $0.1 \mathrm{U} / \mathrm{ml}$ to $0.6-3.1 \mathrm{U} / \mathrm{ml}$ for $l c c 1$ and $2.0-7.5 \mathrm{U} / \mathrm{ml}$ for $l c c 5$ and $l c c 9$ transformants as determined by activity tests in liquid fermentation and further shown in native-PAGE by strongly increased staining activity of those band which was characteristic for the respective laccase gene used in transformation. Only one clone from single-pCcAde8 transformation produced sizeable amounts of laccase $(2.3 \mathrm{U} / \mathrm{ml})$ by overexpression of both Lcc1 and Lcc5 which was probably caused by an unknown mutation in the clone (experiment 1 , Table 2).

In experiment 2 in Table 2 performed with $l c c 9$-antisense constructs, co-transformation rates were determined by integrated DNA from 66 randomly selected OK130 clones, through PCR amplification from genomic DNAs of $l c c 9$-antisense fragments linked with $A$. bisporus gpdII promoter and $l c c 1$ terminator sequences using primers PF and PR (Table 5). Accordingly, 80 and $72 \%$ of the obtained clones were co-transformants of both plasmids. Functionality of inserted DNA in $l c c 9$-silencing was then tested in co-cultivation of transformants in SAHX medium according to Pan et al. [65] with the 


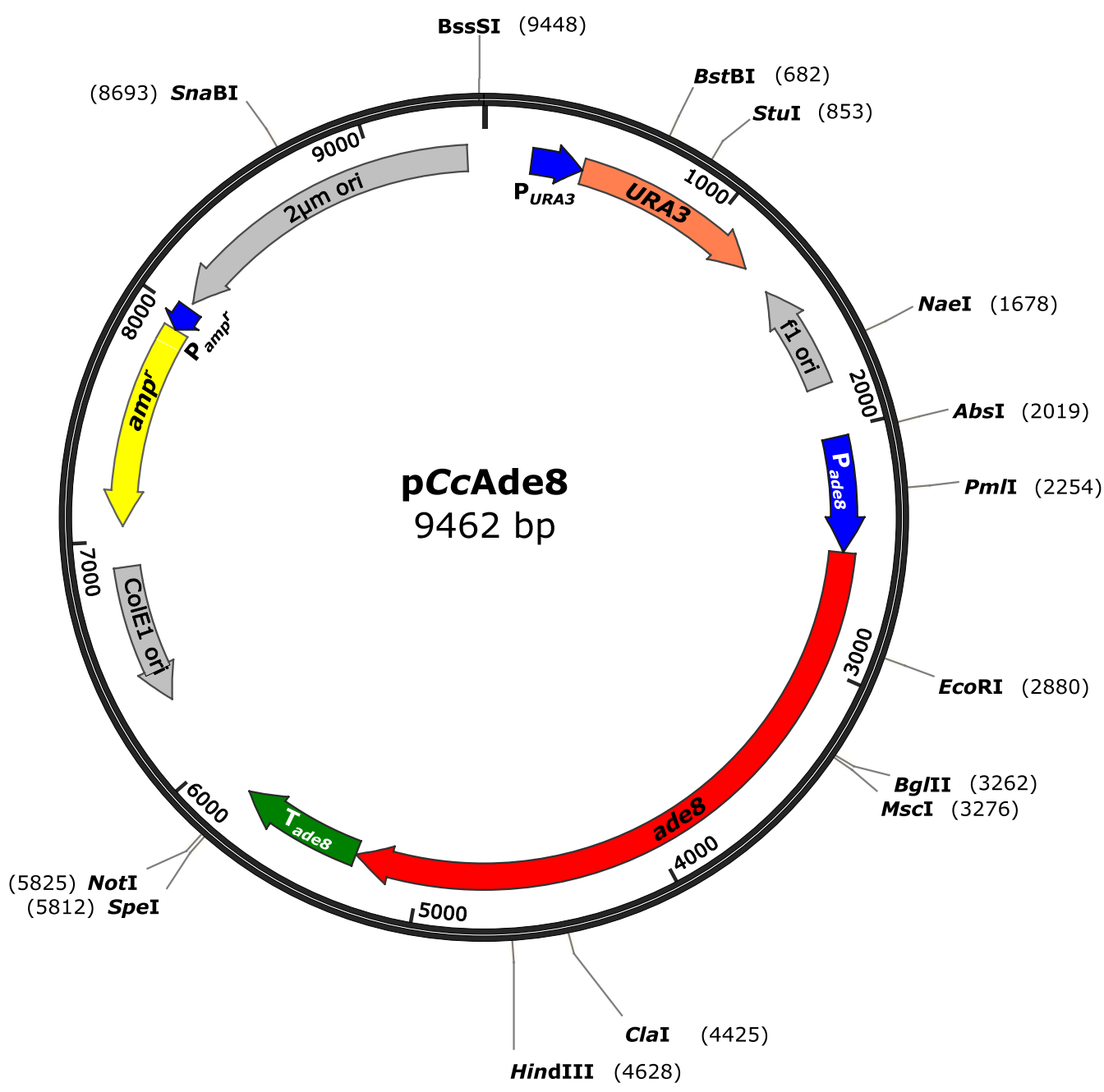

Fig. 3 Physical map of the yeast-E. coli shuttle vector pCCAde8 with the cloned C. cinerea gene ade $8^{+}$

Table 2 Transformations of C. cinerea OK130 (ade8-1) with ade8 ${ }^{+}$-vector pCcAde8 alone or, using same batches of protoplasts, in combination with various pYSK7 laccase gene derivatives

\begin{tabular}{|c|c|c|c|c|c|}
\hline \multirow[t]{2}{*}{ Plasmid(s) } & \multicolumn{4}{|c|}{ ade $8^{+}$-selected transformants collected on* } & \multirow{2}{*}{$\begin{array}{l}\text { Total } \\
\text { transformants* }\end{array}$} \\
\hline & 1 st day & 2nd day & 3rd day & 4th day & \\
\hline \multicolumn{6}{|l|}{ Experiment 1: Laccase overexpression } \\
\hline pCcAde8 & $17(1)$ & 15 & 7 & 2 & 41 \\
\hline pCcAde8 + pYSK7 & $26(8)$ & $20(13)$ & $7(3)$ & $7(1)$ & $60(25)$ \\
\hline pCcAde8 + pYSK-Icc5 & $14(2)$ & $27(8)$ & $25(5)$ & $10(5)$ & $76(20)$ \\
\hline pCcAde8 + pYSK-Icc9 & $10(4)$ & $23(10)$ & $23(5)$ & $8(0)$ & $64(19)$ \\
\hline \multicolumn{6}{|l|}{ Experiment 2: Laccase silencing } \\
\hline pCcAde8 & 17 & 20 & 12 & 6 & 55 \\
\hline pCcAde8 + pYSK-Icc9-antisense-1 & $5(2)$ & $7(2)$ & $12(6)$ & $6(4)$ & $30(14)$ \\
\hline pCcAde8 + pYSK-Icc9-antisense-2 & $2(1)$ & $9(5)$ & $17(12)$ & $8(6)$ & $36(24)$ \\
\hline
\end{tabular}

*Data in brackets of experiment 1 indicate number of clones with $>$ sixfold increased levels of laccase as detected by activity assay in liquid fermentation and nativePAGE; data in brackets of experiment 2 indicate clones with 2- to 11 -fold $\left(2^{-\Delta \Delta C T}\right)$ decreases in Icc 9 mRNA transcriptional levels as detected by qRT-PCR 
Table 3 Transformations of $C$. cinerea FA2222 (trp1.1,1.6) with plasmid pBD5 alone or, using same batches of protoplasts, in combination with other non-directly selectable vectors

\begin{tabular}{|c|c|c|c|c|c|c|c|}
\hline \multirow[t]{2}{*}{ Plasmid(s) } & \multicolumn{5}{|c|}{$\operatorname{trp} 1^{+}$-selected transformants collected on } & \multirow[t]{2}{*}{ Total transformants } & \multirow[t]{2}{*}{ Ratio of clones } \\
\hline & 1 st day & 2nd day & 3rd day & 4th day & 5th day & & \\
\hline \multicolumn{8}{|l|}{ Experiment 1} \\
\hline pBD5 & 13 & 8 & 12 & 3 & 2 & 38 & 1.0 \\
\hline $\mathrm{pBD} 5+\mathrm{pYSK} 7^{*}$ & $30(8)$ & $20(13)$ & $32(7)$ & $9(2)$ & $4(2)$ & $95(32)$ & 2.5 \\
\hline $\mathrm{pBD} 5+\mathrm{pDB} 3$ & 32 & 13 & 25 & 6 & 3 & 79 & 2.1 \\
\hline $\mathrm{pBD} 5+\mathrm{pPAB} 1-2$ & 18 & 17 & 17 & 7 & 2 & 61 & 1.6 \\
\hline pBD5 + pCcAde8 & 34 & 27 & 11 & 4 & 2 & 78 & 2.1 \\
\hline \multicolumn{8}{|l|}{ Experiment 2} \\
\hline pBD5 & 46 & 38 & 28 & 12 & 11 & 135 & 1.0 \\
\hline $\mathrm{pBD} 5+\mathrm{pYSK} 7^{*}$ & $94(31)$ & $89(22)$ & $68(27)$ & $15(12)$ & $5(3)$ & $271(95)$ & 2.0 \\
\hline $\mathrm{pBD} 5+\mathrm{pDB} 3$ & 69 & 52 & 53 & 15 & 12 & 201 & 1.5 \\
\hline $\mathrm{pBD} 5+\mathrm{pPAB} 1-2$ & 76 & 78 & 49 & 28 & 14 & 245 & 1.8 \\
\hline pBD5 + pCcAde8 & 100 & 114 & 90 & 26 & 14 & 344 & 2.5 \\
\hline
\end{tabular}

*Date in brackets indicate clones expressing laccases as deduced from stained halos around their colonies. Non-producers of laccase did not stain the agar. Random subsets of unstained pBD5 and of staining pBD5 + pYSK7 clones from both experiments were further tested in liquid fermentations

Table 4 Transformations of $C$. cinerea PG78 (trp1.1,1.6, pab1-1) with either $\operatorname{trp} 1^{+}$plasmid pBD5 or pab1 ${ }^{+}$vector pPAB1-2 alone or, using same batches of protoplasts, in combination with other non-directly selectable vectors

\begin{tabular}{|c|c|c|c|c|c|c|c|c|c|}
\hline \multirow[t]{2}{*}{ Plasmid(s) } & \multicolumn{7}{|c|}{ Transformants collected on } & \multirow{2}{*}{$\begin{array}{l}\text { Total } \\
\text { transformants }\end{array}$} & \multirow[t]{2}{*}{ Ratio of clones } \\
\hline & 1st day & 2nd day & 3rd day & 4th day & 5th day & 6th day & 7th day & & \\
\hline \multicolumn{10}{|c|}{ Experiment 1: $\operatorname{trp} 1^{+}$selection } \\
\hline pBD5 & - & - & - & 21 & 26 & 14 & 6 & 67 & 1.0 \\
\hline pBD5 + pYSK7 & 10 & 16 & 31 & 31 & 14 & 4 & 0 & 106 & 1.6 \\
\hline $\mathrm{pBD} 5+\mathrm{pDB} 3$ & 2 & 4 & 0 & 50 & 69 & 15 & 12 & 152 & 2.3 \\
\hline $\mathrm{pBD} 5+\mathrm{pCc}$ Ade8 & - & - & - & 45 & 67 & 20 & 16 & 148 & 2.2 \\
\hline \multicolumn{10}{|l|}{ pab1+ selection } \\
\hline pPAB1-2 & 40 & 18 & 14 & 8 & - & - & - & 80 & 1.0 \\
\hline pPAB1-2+ pYSK7 & 40 & 13 & 40 & 11 & - & - & - & 104 & 1.3 \\
\hline $\mathrm{pPAB} 1-2+\mathrm{pDB} 3$ & 53 & 11 & 31 & 8 & 4 & - & - & 107 & 1.3 \\
\hline pPAB1-2 + pBD5 & 14 & 6 & 19 & 13 & 15 & 3 & - & 70 & 0.9 \\
\hline pPAB1-2 + pCcAde8 & 59 & 32 & 49 & 9 & 3 & - & - & 152 & 1.9 \\
\hline \multicolumn{10}{|c|}{ Experiment 2: $\operatorname{trp} 1^{+}$selection } \\
\hline pBD5 & 20 & 21 & 20 & 15 & 7 & - & - & 83 & 1.0 \\
\hline pBD5 + pYSK7 & 26 & 42 & 31 & 13 & 13 & - & - & 125 & 1.5 \\
\hline $\mathrm{pBD} 5+\mathrm{pDB} 3$ & 34 & 38 & 29 & 13 & 7 & - & - & 121 & 1.5 \\
\hline pBD5 + pCcAde8 & 18 & 27 & 49 & 16 & 12 & - & - & 122 & 1.5 \\
\hline \multicolumn{10}{|l|}{$p a b 1^{+}$selection } \\
\hline pPAB1-2 & 25 & 29 & 50 & 19 & 13 & & - & 136 & 1 \\
\hline pPAB1-2+ pYSK7 & 40 & 19 & 37 & 37 & 12 & - & - & 145 & 1.1 \\
\hline pPAB1-2 + pDB3 & 33 & 46 & 33 & 26 & 17 & - & - & 155 & 1.1 \\
\hline pPAB1-2 + pBD5 & 7 & 30 & 37 & 25 & 18 & - & - & 117 & 0.9 \\
\hline pPAB1-2+ pCcAde8 & 37 & 32 & 54 & 38 & 18 & - & - & 177 & 1.3 \\
\hline
\end{tabular}

fungus Gongronella sp. w5 which induces lcc9 expression in OK130 [65, 67]. Using cDNAs from co-cultivated OK130 transformants and qRT-lcc9-F and qRT-lcc9-R as primers (Table 5), qRT-PCR analysis revealed silencing ratios of $l c c 9$ in $47 \%$ and $67 \%$ of all transformants for the two $l c c 9$ antisense constructs, respectively. 


\section{The bacterial $h p h$ gene in OK130 transformations}

We also used vector pCRII-hph with an integrated antisense-lcc 9 fragment for transformation of monokaryon OK130 under hygromycin B resistance selection. Transformation rates in 5 rounds of experiments were not as efficient, with only between 7 to 15 transformants per $1 \mu \mathrm{g}$ plasmid DNA. After re-screening on new plates containing $200 \mathrm{mg} / \mathrm{l}$ hygromycin B, 40 of a total of 70 transferred clones $(=57 \%)$ failed to grow. Noteworthy, the tolerance of OK130 to hygromycin B varied among different batches of experiments. Screening under a constant hygromycin B concentration of $200 \mathrm{mg} / \mathrm{l}$ in the overlay on regeneration agar plates did not always work, leading sometimes to high proportions of false-positive transformants. Of the 30 remaining hygromycin B-resistant clones tested positive by PCR for $h p h$ integration, $12(=40 \%)$ were silenced for laccase Lcc9 production as determined by qRT-PCR analysis of cDNAs from transformants co-cultured with Gongronella sp. w5. In summary, $h p h$ selection and transformation efficiencies were inferior to the $a d e 8^{+}$selection and transformation efficiencies in OK130 with vector pCcAde 8 while $l c c 9$ silencing frequencies in co-transformants were nearly as good.

\section{Conclusions}

In this work, we have constructed pCcAde8 as a new selection vector for transformations of $C$. cinerea strains with ade 8 auxotrophies, such as the sequenced reference monokaryon OK130. Co-transformation rates of genes expressed from unselected vectors transformed with pCcAde 8 were between 26 and $67 \%$ in ranges as observed in co-transformations with other selection markers in other strains. Using gene $a d e 8^{+}$for selection, this had no recognizable negative feedback effects on reducing numbers of viable transformants, similar as when using the $\mathrm{pab1}^{+}$selection marker of C. cinerea for pab1 complementations and unlike as experienced with the $\operatorname{trp} 1^{+}$ selection marker in trp1-auxotrophic C. cinerea strains. $p a b 1^{+}$can be used to complement the pab1-1 defect in the also sequenced homokaryon AmutBmut. Defects in the mutated ade8-1 and pab1-1 alleles in the two sequenced $C$. cinerea reference strains were defined as missense mutations in the N-terminal GARS domain of the bifunctional GARS-AIRS enzyme from the de novo purine biosynthesis pathway and in the $\mathrm{C}$-terminal $\mathrm{PabB}$ domain of the bifunctional 4-amino-4-deoxychorismate synthase in the PABA biosynthesis pathway, respectively.

We have used $l c c 9$-antisense constructs in co-transformation of strain OK130 with pCcAde8 in order to suppress native laccase production at high frequency in resulting transformants. Other attempts of $l c c 9$ silencing were made with a single vector carrying an $h p h$ selection marker and in addition cloned $l c c 9$-antisense sequences

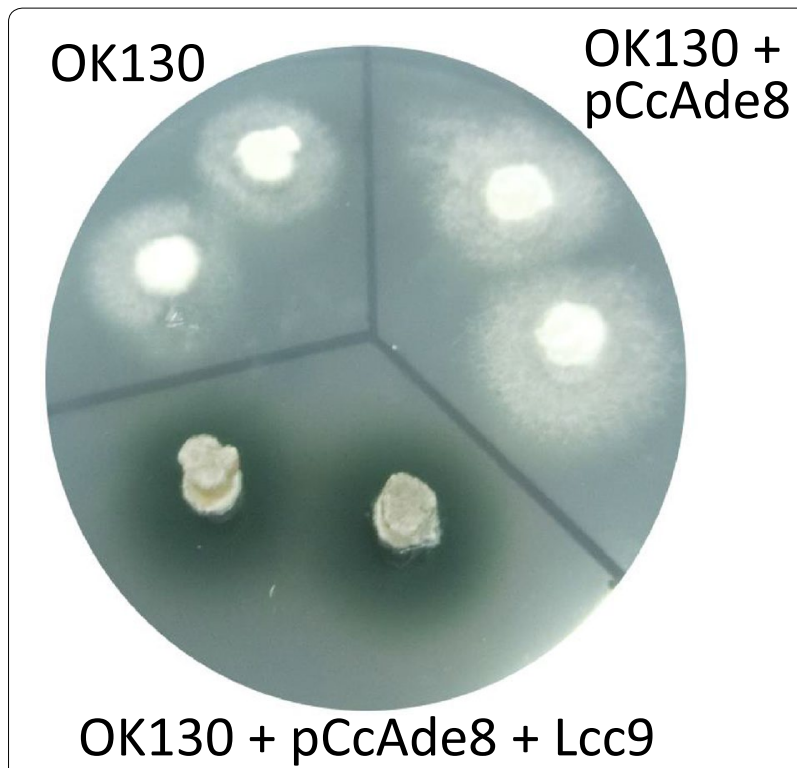

Fig. 4 Untransformed ade8-1 monokaryon OK130 (top left) and pCcAde8 transformed clones (top right) with barely detectable halos from background laccase activity on ABTS and pCCAde8 + pYSK-Icc9 transformants (bottom) with strongly stained broad halos of enzymatically oxidized ABTS. Clones were grown on regeneration agar medium which $0.5 \mathrm{mM}$ ABTS and $50 \mathrm{mg} / \mathrm{L}$ adenine sulphate

for gene silencing. This second selection system is independent of a gene defect in a host strain. It is in principle also working, but was less efficient in transformation rates than using the $\mathrm{pCcAde} 8$ vector in single-vector transformation and in co-transformation. By its better transformation efficiency, ade $8^{+}$selection would thus be the first choice for transformation of the $C$. cinerea reference monokaryon OK130. Nevertheless, when further rounds of transformations in the same strain background are required, $h p h$ selection offers extra possibilities after a complementation of the ade8-1 defect in OK130 by transfer of $a d e 8^{+}$.

\section{Methods}

Strains, transformation and growth conditions

Monokaryons Okayama 7/\#130 (short name in literature OK130 [8]; ATCC MYA-4618, FGSC 9003; genotype: A43, B43, ade8-1), FA2222 (DSM 28333; A5, B6, acu1, trp1.1,1.6 [69]) and PG78 (DSM 28337; A6, B42, pab1-1,

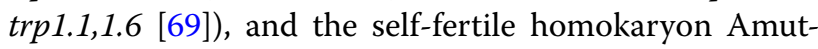
Bmut (FGSC 25122; genotype: A43mut, B43mut, pab11 [69]) were routinely cultivated on YMG/T medium at $37^{\circ} \mathrm{C}$ [3]. Oidia per fully grown plates were harvested in sterile water, filtered through sterile glass wool, washed, protoplasted and transformed as described before [3, 4]. For fungal transformation, plasmid DNA with bacterial RNA was isolated from $3 \mathrm{ml} E$. coli XL1-Blue (Agilent, 
Table 5 Primers used in this study

\begin{tabular}{|c|c|c|}
\hline Name & Sequence $\left(5^{\prime}-3^{\prime}\right)$ & Purpose \\
\hline ade8_f & $\begin{array}{l}\text { GAATTGGGTACCGGGCCCCCCCTCGAGGTCGACTGGCCGTTCATA } \\
\text { GCGATGTC (sequence upstream of the HindIII-site in pRS426 } \\
\text { in italic, sequence upstream of ade } 8^{+} \text {in normal letters) }\end{array}$ & Cloning of ades $^{+}$in pCcAdes \\
\hline ade8_r & $\begin{array}{l}\text { GCCGCTCTAGAACTAGTGGATCCCCCGGGCTGAGCTCGTTTCCATCG } \\
\text { TCATCA (sequence downstream of the ECoRI-site in pRS426 } \\
\text { in italic, sequence downstream of ade } 8^{+} \text {in normal letters) }\end{array}$ & Cloning of ade $^{+}$in pCcAde 8 \\
\hline Lcc5-fwd & $\begin{array}{l}\text { CTCCCATCTACACACAACAAGCTTATCGCCATGTCGTTTGCTTGG } \\
\text { AAAGCATTGGC (A. bisporus } P_{g p d} \text { sequence is in italic, ICc5 } \\
\text { sequence in normal letters) }\end{array}$ & Cloning of Icc5 for overexpression in pYSK-Icc5 \\
\hline Lcc5-rev & $\begin{array}{l}\text { CCACTGGCCCTCTGGTCAACTATAATATTATTTAGGGATACATAGG } \\
\text { GAGCAAGTTCGAA ( } T_{\text {Iccl }} \text { sequence is in italic, Icc5 sequence } \\
\text { in normal letters) }\end{array}$ & Cloning of Icc5 for overexpression in pYSK-Icc5 \\
\hline Lcc9-fwd & $\begin{array}{l}\text { CTCCCATCTACACACAACAAGCTTATCGCCATGTCCAGGAAACTT } \\
\text { TTCTCTCTCGCC (A. bisporus } P_{g p d} \text { sequence is in italic, IcC9 } \\
\text { sequence in normal letters) }\end{array}$ & Cloning of Icc9 for overexpression in pYSK-Icc9 \\
\hline Lcc9-rev & $\begin{array}{l}\text { CCACTGGCCCTCTGGTCAACTATAATATTATTTAAGGAGTGGGGAC } \\
\text { AATTTGGATAGAGGT ( } \mathrm{T}_{\text {Iccl }} \text { sequence is in italic, Icc9 sequence } \\
\text { in normal letters) }\end{array}$ & Cloning of Icc9 for overexpression in pYSK-Icc9 \\
\hline Lcc9-antisense 1-fwd & $\begin{array}{l}\text { CTCCCATCTACACACAACAAGCTTATCGCCCGGGATTCTCATAGT } \\
\text { TGTAAGTGCTGC (A. bisporus } P_{\text {gpd }} \text { sequence is in italic, IcC9 } \\
\text { antisense } 1 \text { sequence in normal letters) }\end{array}$ & Cloning of Icc9-antisense fragment 1 in pYSK-Icc9-antisense-1 \\
\hline Lcc9- antisense 1-rev & $\begin{array}{l}\text { CACTGGCCCTCTGGTCAACTATAATATTATAGATGGGCCTTGGAC } \\
\text { CTGCCG ( } T_{\text {lccl }} \text { sequence is in italic, Icc } 9 \text { antisense } 1 \text { sequence } \\
\text { in normal letters) }\end{array}$ & Cloning of Icc9-antisense fragment 1 in pYSK-Icc9-antisense-1 \\
\hline Lcc9- antisense 2-fwd & $\begin{array}{l}\text { CTCCCATCTACACACAACAAGCTTATCGCCCGGACCACTTCCTCC } \\
\text { TGGGGCA (A. bisporus } P_{\text {gpd }} \text { sequence is in italic, lcc9 anti- } \\
\text { sense } 2 \text { sequence in normal letters) }\end{array}$ & Cloning of Icc9-antisense fragment 2 in pYSK-Icc9-antisense- 2 \\
\hline Lcc9- antisense 2-rev & $\begin{array}{l}\text { CACTGGCCCTCTGGTCAACTATAATATTATCTCTCATGGTCGACG } \\
\text { AAATCCAGATC ( } T_{\text {Iccl }} \text { sequence is in italic, lcc9 antisense } 2 \\
\text { sequence in normal letters) }\end{array}$ & Cloning of Icc9-antisense fragment 2 in pYSK-Icc9-antisense- 2 \\
\hline$P_{g p d}-F$ & $\begin{array}{l}\text { GATATCGAAGAAGAATTCAGAGGTCCGCAAGTA (A. bisporus } P_{\text {gpd }} \\
\text { sequence, ECoRV site underlined) }\end{array}$ & $\begin{array}{l}\text { Cloning of A. bisporus gpdll promotor for pCRII-hph-lcc9 vector } \\
\text { construction }\end{array}$ \\
\hline$P_{g p d^{-}} \mathrm{R}$ & $\begin{array}{l}\text { AAGTGGTCCGGGCGATAAGCTTGTTGTGTGTAGATGG (A. bisporus } \\
P_{\text {gpd }} \text { sequence is in italic, Icc9 antisense } 2 \text { sequence in normal } \\
\text { letters) }\end{array}$ & $\begin{array}{l}\text { Cloning of A. bisporus gpdll promotor for pCRII-hph-/cc9 vector } \\
\text { construction }\end{array}$ \\
\hline Lcc9-antisense-hphF & $\begin{array}{l}\text { GCTTATCGCCCGGACCACTTCCTCCTGGGGCA (A. bisporus } P_{\text {gpd }} \\
\text { sequence is in italic, lcc9 antisense } 2 \text { sequence in normal } \\
\text { letters) }\end{array}$ & $\begin{array}{l}\text { Cloning of Icc9 antisense fragment } 2 \text { for pCRII-hph-Icc9 vector } \\
\text { construction }\end{array}$ \\
\hline Lcc9-antisense-hphR & $\begin{array}{l}\text { TGCTATGACTCTCTCATGGTCGACGAAATCCAGATC ( } T_{\text {Icc } 9} \\
\text { sequence is in italic, ICC } 9 \text { antisense } 2 \text { sequence in normal } \\
\text { letters) }\end{array}$ & $\begin{array}{l}\text { Cloning of Icc } 9 \text { antisense fragment } 2 \text { for pCRII-hph-Icc9 vector } \\
\text { construction }\end{array}$ \\
\hline $\mathrm{T}_{/ C C 9^{-}}-\mathrm{F}$ & $\begin{array}{l}\text { ACCATGAGAGAGTCATAGCACATAGCCATACCGACAC ( } T_{\text {Icc9 }} \\
\text { sequence is in italic, ICC } 9 \text { antisense } 2 \text { sequence in normal } \\
\text { letters) }\end{array}$ & $\begin{array}{l}\text { Cloning of C. cinerea lcc9 terminator for pCRII-hph-Icc9 vector } \\
\text { construction }\end{array}$ \\
\hline $\mathrm{T}_{\text {/cc }}-\mathrm{R}$ & $\frac{\text { GGGCCCGTCAAAGGAGTCAGCCCTTGGACATG (T/cc9 }}{\text { Apal site underlined) }}$ & $\begin{array}{l}\text { Cloning of C. cinerea lcc9 terminator for pCRII-hph-lcc9 vector } \\
\text { construction }\end{array}$ \\
\hline DPf & $\begin{array}{l}\text { ATGTCGATCCGCATCCTACTCCTC (sequence of ades from } \\
\text { startcodon onwards) }\end{array}$ & Diagnosis PCR for nuclear ade $8^{+}$insertion \\
\hline $\mathrm{DPr}$ & $\begin{array}{l}\text { ATCCCAGGCGGAGAGATTGCG (sequence of ade } 8 \text { with its last } \\
\text { triplets for amino acids) }\end{array}$ & Diagnosis PCR for nuclear ade $8^{+}$insertion \\
\hline PF & $\begin{array}{l}\text { ACATCCACCATCTCCGTTTTCTCCCAT (A. bisporus } \mathrm{P}_{g p d} \\
\text { sequence) }\end{array}$ & PCR of OK130 co-transformants of Icc9-antisense-constructs \\
\hline PR & TGACTATAGCAGCCTCCTACCACTG ( $T_{\text {Iccl }}$ sequence) & PCR of OK130 co-transformants of Icc9-antisense-constructs \\
\hline qRT-Icc9-F & ATGTCCAGGAAACTTTTCTCTCTCG (IcC9 sequence + 1 to +25$)$ & qRT-PCR of Icc9 \\
\hline qRT-Icc9-R & $\begin{array}{l}\text { ATGTTCGAGACCGTCATGGTACT (reverse complementary lcc9 } \\
\text { sequence of + } 79 \text { to + 101) }\end{array}$ & qRT-PCR of Icc9 \\
\hline
\end{tabular}


Böblingen, Germany) overnight LB (amp) cultures by a modified Birnboim-Doly method [4]. Per transformation sample and per plasmid, $1 \mu \mathrm{g}$ plasmid DNA was used. When required for testing laccase activities in transformants, $0.5 \mathrm{mM}$ ABTS was added to regeneration agar [16]. Prototrophic transformants appeared at first on regeneration agar 3.5-4 days after plating $(=1$ st day of picking clones reported in Tables 2,3,4). Day by day, all new clones were counted and collected from regeneration agar onto minimal medium with suitable supplements $[3,4]$. Using in experiments the same protoplast batches, ratios of transformants were calculated by dividing the total number of clones obtained by a co-transformation by the total number of clones obtained from the single-vector transformation under the same scheme of selection. For selection for hygromycin B resistance after transformation, an extra $5 \mathrm{ml}$ of regeneration agar (low melting point agar, $1 \%$ ) containing $200 \mathrm{mg} / \mathrm{l}$ hygromycin $\mathrm{B}$ were overlaid after protoplast plating on regeneration agar. Individual hygromycin B-resistant transformants which appeared on these plates were re-screened by culturing again on regeneration agar containing $200 \mathrm{mg} / \mathrm{l}$ hygromycin B. hph-transformants were further verified based on PCR amplification of a gpdII promoter-lcc9 antisense-lcc 9 terminator fragment with their genomes as templates and $\mathrm{P}_{g p d}-\mathrm{F}$ and $\mathrm{T}_{l c c 9}-\mathrm{R}$ as primers (Table 5). OK130 transformants for $l c c 9$ silencing were cultured in SAHX medium using sucrose as the carbon source and cocultivation with Gongronella sp. w5 for $l c c 9$ induction according to Pan et al. [65]. qRT-PCR analysis using qRTlcc9-F and qRT-lcc9-R as primers and transformants' cDNAs as substrate was performed to further evaluate their silencing ratios [72]. For laccase activity tests in fermentation, clones were grown in YMG medium and supernatants of the culture broth were withdrawn every $12 \mathrm{~h}$ for activity assay and native-PAGE was performed as previously described [65]. Lcc1, Lcc5 and Lcc9 can be well distinguished in native-PAGE by differential migration patterns $[64,65]$.

\section{pCcAde8 vector construction}

Chimeric primers ade8_f and ade8_r (Table 5) were designed from the AmutBmut genome for PCR amplification of the wt ade $8^{+}$gene from chromosomal DNA using Phusion High-Fidelity DNA polymerase (Thermo Fisher Scientific Inc., Darmstadt, Germany). The amplified DNA fragment was transformed into the $\Delta u$ ra 3 yeast strain RH 1385 [70] together with the HindIIIEcoRI double-digested E. coli-yeast shuttle $u r a 3^{+}$-vector pRS426 [60] for in vivo plasmid construction by homologous recombination [71]. Plasmids were isolated from prototrophic yeast clones and further amplified in E. coli XL1-Blue. Proper fragment insertion was confirmed by sequencing as described [6]. Diagnosis PCR for insertion of pCcAde8 in nuclear DNA of transformants was performed with primers DPf and DPr (Table 5) which amplify the complete ade8 coding region. Sequencing of the amplicons from 25 randomly selected transformants verified insertion of $a d e 8^{+}$copies by presence of either a wt A (1x) or a mixture of an A and a mutant G (24x) at position 691 in codon 231 of the gene.

\section{Other plasmids}

trp $1^{+}$-vector $\mathrm{pBD} 5$ and $\operatorname{trp} 3^{+}$-vector pDB3 are described in [5] and [7], respectively. pPAP1-2 is a pTZ18R-based $\mathrm{pabl}^{+}$selection vector [3]. Plasmid pYSK7 is a pRS426 [60] derivate containing the $C$. cinerea laccase gene $l c c 1$ cloned behind the A. bisporus gpdII promoter and with its own terminator [16]. pYSK- $l c c 5$ and pYSK- $l c c 9$ were generated through in vivo recombination in yeast [71] of PCR-amplified OK130 cDNA (for primers, please see Table 5) with BamHI and HpaI linearized plasmid pYSK7. Similarly, pYSK-lcc9-antisense-1 and pYSK$l c c 9$-antisense- 2 were constructed by amplifying $l c c 9$ sequences with primers Lcc9-antisense 1/2-fwd and Lcc9-antisense 1/2-rev (see Table 5) from strain OK130 and inserting the resulting fragments $(l c c 9$-antisense 1 is from $\mathrm{bp}+305$ to +514 of $l c c 9$; $l c c 9$-antisense 2 is from $\mathrm{bp}+752$ to +1032 of the gene) into BamHI and HpaI linearized plasmid pYSK7 through in vivo recombination in yeast [71]. The $l c c 9$-antisense 2 plasmid pCRII$h p h-l c c 9$ was constructed based on the pCRII-TOPO derivative pCRII- $h p h$ which contains in the vector TOPO TA-cloning site a $1.0 \mathrm{~kb} \beta$-tubulin promoter and a $0.5 \mathrm{~kb}$ terminator sequence of Trametes hirsuta $\mathrm{AH} 28-2$ and the bacterial $h p h$ gene in between [72]. Briefly, a $281 \mathrm{bp}$ reverse complementary sequence cloned from cDNA of laccase gene $l c c 9(\mathrm{bp}+752$ to +1032$)$ was joined to the A. bisporus gdpII promoter sequence $(277 \mathrm{bp})$ and the C. cinerea lcc 9 terminator sequence $(500 \mathrm{bp}$ ) by overlapping PCR using the primer pairs of $\mathrm{P}_{g p d}-\mathrm{F}$ and $\mathrm{P}_{g p d}-\mathrm{R}$, and $\mathrm{T}_{l c c 9}-\mathrm{F}$ and $\mathrm{T}_{l c c-9}-\mathrm{R}$ listed in Table 5. The fused sequences were then digested with EcoRV and ApaI and inserted into the EcoRV and ApaI polylinker sites of pCRII- $h p h$.

\section{Sequence analyses}

The published genomes of monokaryon Okayama 7/\#130 (https://mycocosm.jgi.doe.gov/Copci1/Copci1.home. html) and homokaryon AmutBmut (https://mycocosm. jgi.doe.gov/Copci_AmutBmut1/Copci_AmutBmut1. home.html) on the JGI Mycocosm side were used for defining chromosomal loci of genes of interest and obtaining relevant DNA and protein sequences. Protein sequences from E. coli and S. cerevisiae (Table 1) were used in tblastn searches. Homologous protein sequences retrieved from the JGI homepages and from NCBI were 


\section{aligned by ClustalX 2.0 [73] and the MEGA 6.0 software was used with 1000 bootstrap values for constructing a neighbor-joining tree [74].}

\begin{abstract}
Abbreviations
ABTS: 2,2'-Azino-bis (3-ethylbenzothazoline-6-sulfonic acid); ADC: 4-Amino4-deoxychorismate; ADP: Adenosine diphosphate; AICAR: 5'-Phosphoribosyl5-monophosphate; AIR: Aminoimidazole ribonucleotide; AIRS: Aminoimidazole ribonucleotide synthase; AMP: Adenosine monophosphate; ATP: Adenosine triphosphate; CAIR: 5-Amino-4-imidazolecarboxamide ribonucleotide; DHF: Dihydrofolic acid; DHNTP: 7,8-Dihydroneopterin 3'-triphosphate; DHP: Dihydropteroate; FAICAR: 5-Formamidoimidazole-4-carboxamide ribotide; FGAM: Formylglycinamide ribonucleotide; FGAMS: Formylglycinamide ribonucleotide synthase; FGAR: Phosphoribosyl-N-formylglycinamide; GAR: Glycinamide ribonucleotide; GARS: Glycinamide ribonucleotide synthase: GART: Phosphoribosylglycinamide formyltransferase; GATase: Glutamine amidotransferase; GPAT: Glutamine amidophosphoribosyltransferase; GTP: Guanosine-5'-triphosphate; HIT: Histidine triad; IGP: Indole-3-glycerol-phosphate; IGPS: Indol-3-glycerol-phosphate synthase; IMP: Inosine monophosphate; NAD: Nicotinamide adenine dinucleotide; NADP: Nicotinamide adenine dinucleotide phosphate; 3PHP: 3-Phosphohydroxypyruvate; PABA: para-Aminobenzoic acid; PAGE : Polyacrylamide gel electrophoresis; 3PG: 3-Phosphoglyceric acid; Pi: Phosphate; PRA: Phosphoribosylamine; PRAl: Phosphoribosylanthranilate isomerase; PRPP: 5-Phosphoribosyl-a-1-pyrophosphate; SAICAR: Phosphoribosylaminoimidazole-succinocarboxamide; SAICARS: Phosphoribosylaminoimidazole-succinocarboxamide synthase; SDH: Succinate dehydrogenase; SAMP: Succinyladenosine 5'-monophosphate; THF: Tetrahydrofolate; wt: Wildtype.
\end{abstract}

\section{Acknowledgements}

There are no further acknowledgements.

\section{Authors' contributions}

UK, ZF and BD perceived the study, UK and BD analyzed C. cinerea DNA and protein sequences, $C P, A K$ and $B D$ constructed vectors, $Z F, C P$ and $C Y$ transformed C. cinerea, CP performed PCR analyses, UK and ZF analyzed data and wrote the paper, and all authors commented on the manuscript. All authors read and approved the final manuscript.

\section{Funding}

Open Access funding enabled and organized by Projekt DEAL. ZF acknowledges funding by the Key Research Program of the Department of Education of Anhui Province (KJ2017ZD04) and a fellowship by the Chinese Scholarship Council (201706505019) for a one-year stay as a guest scientist in the laboratory in Göttingen, AK and CY received scholarships from the Karachi University Scholarship Fund for a PhD and from the Syiah Kuala University for stay in Germany, respectively.

\section{Availability of data and materials}

No larger data sets were generated and analyzed during this study. Vectors are available from the authors.

\section{Ethics approval and consent to participate}

Not applicable.

\section{Consent for publication}

Not applicable.

\section{Competing interests}

The authors declare no competing interests.
Author details
${ }^{1}$ Molecular Wood Biotechnology and Technical Mycology, Büsgen-Institute, University of Goettingen, Büsgenweg 2, 37077 Goettingen, Germany. ${ }^{2}$ Goettingen Center for Molecular Biosciences (GZMB), University of Goet- tingen, Goettingen, Germany. ${ }^{3}$ School of Life Sciences, Anhui University, Hefei 230601, China. ${ }^{4}$ Anhui Key Laboratory of Modern Biomanufacturing,

Hefei 230601, China. ${ }^{5}$ Present Address: Institute for Microbiology and Genetics, University of Goettingen, 37077 Goettingen, Germany.

Received: 3 July 2020 Accepted: 30 September 2020

Published online: 12 October 2020

\section{References}

1. Binninger DM, Skrzynia C, Pukkila PJ, Casselton LA. Targeted transformation in Coprinus cinereus. Mol Gen Genet. 1987;227:245-51.

2. Casselton $L A$, de la Fuente Herce $A$. Heterologous gene expression in the basidiomycete fungus Coprinus cinereus. Curr Genet. 1989;16:35-40.

3. Granado JD, Kertesz-Chaloupková K, Aebi M, Kües U. Restriction enzyme-mediated DNA integration in Coprinus cinereus. Mol Gen Genet. 1997;256:28-36.

4. Dörnte B, Kües U. Reliability in transformation of the basidiomycete Coprinopsis cinerea. Curr Trends Biotechnol Pharm. 2012;6:340-55.

5. Dörnte B, Kües U. Paradoxical performance of tryptophan synthase gene $\operatorname{trp~}^{+}$in transformations of the basidiomycete Coprinopsis cinerea. Appl Microbiol Biotechnol. 2016;100:8789-807.

6. Dörnte B, Kües U. Split trp $1^{+}$gene markers for selection in sequential transformations of the Agaricomycete Coprinopsis cinerea. Curr Biotechnol. 2016:6:139-48.

7. Burrows DM. Transformation studies with the basidiomycete fungi Coprinus cinereus and Coprinus bilanatus. Dissertation, London, UK: University of London; 1991.

8. Kües U, Richardson WVJ, Tymon AM, Mutasa ES, Göttgens B, Gaubatz $S$, et al. The combination of dissimilar alleles of the $A a$ and $A \beta$ gene complexes, whose proteins contain homeo domain motifs, determines sexual development in the mushroom Coprinus cinereus. Genes Dev. 1991;6:568-77.

9. Bhattiprolu GR, Challen MP, Elliott TJ. Transformation of the homobasidiomycete Coprinus bilanatus to 5 -fluoroindole resistance using a mutant trp3 gene from Coprinus cinereus. Mycol Res. 1993;97:1281-6.

10. Bottoli APF, Kertesz-Chaloupková K, Boulianne RP, Granado JD, Aebi M, Kües $U$. Rapid isolation of genes from an indexed genomic library of $C$. cinereus in a novel pab1+ cosmid. J Micobiol Meth. 1999;35:129-41.

11. James TY, Boulianne RP, Bottoli APF, Granado JD, Aebi M, Kües U. The pab1 gene of Coprinus cinereus encodes a bifunctional protein for para-aminobenzoic acid (PABA) synthesis: implications for the evolution of fused PABA synthases. J Basic Microbiol. 2002;42:91-103.

12. Botet J, Mateos L, Revuelta JL, Santos MA. A chemogenomic screening of sulfanilamide-hypersensitive Saccharomyces cerevisiae mutants uncovers $A B Z 2$, the gene encoding a fungal aminodeoxychorismate lyase. Eukaryot Cell. 2007:6:2102-11.

13. Casselton LA, Mutasa ES, Tymon A, Mellon FM, Little PFR, Taylor S, et al. The molecular analysis of basidiomycete mating type genes. In: Nevalainen $\mathrm{H}$, Penttilä M, editors. Proceedings of the EMBO-Alko workshop on molecular biology of filamentous fungi, vol. 6. Helsinki: Foundation of Biotechnical and Industrial Fermentation Research; 1989. p. 139-148.

14. Kilaru S, Collins CM, Hartley AJ, Burns C, Foster GD, Bailey AM. Investigating dominant selection markers for Coprinopsis cinerea: a carboxin resistance system and re-evaluation of hygromycin and phleomycion resistance vectors. Curr Genet. 2009:55:543-50.

15. Ito $Y$, Muraguchi $H$, Seshime $Y$, Oita S, Yanagi S. Flutonil and carboxin resistance in Coprinus cinereus conferred by a mutation in the cytochrome $b_{560}$ subunit of succinate dehydrogenase complex (Complex II). Mol Gen Genet. 2004;272:328-35.

16. Kilaru S, Hoegger PJ, Majcherczyk A, Burns C, Shishido K, Bailey A, et al. Expression of laccase gene Iccl in Coprinopsis cinerea under control of various basidiomycetous promoters. Appl Microbiol Biotechnol. 2006;71:200-10.

17. Cummings WJ, Celerin M, Brunick LK, Zolan ME. Insertional mutagenesis in Coprinus cinereus: use of a dominant selectable marker to generate tagged, sporulation-defective mutants. Curr Genet. 1999;36:371-82.

18. Marmeisse R, Gay G, Debaud JC, Casselton LA. Genetic transformation of the symbiotic basidiomycete fungus Hebeloma cylindrosporum. Curr Genet. 1992;22:41-5. 
19. Lima JO, dos Santos JK, Pereira JF, de Resende MLV, de Araujo EF, de Queiroz MV. Development of a transformation system for Crinipellis perniciosa, the causal agent of witches' broom in cocoa plants. Curr Genet. 2003;42:236-40

20. Stajich JE, Wilke SK, Åhren D, Au CH, Birren BW, Borodovsky M, et al. Insights into evolution of multicellular fungi from the assembled chromosomes of the mushroom Coprinopsis cinerea (Coprinus cinereus). Proc Natl Acad Sci USA. 2012;107:11889-94.

21. Muraguchi H, Umezawa K, Niikura M, Yoshida M, Kozaki T, Ishii K, et al. Strand-specific RNA-seq analyses of fruiting body development in Coprinopsis cinerea. PLoS ONE. 2015;10:e0141586.

22. Liu Y, Srivilai P, Loos S, Aebi M, Kües U. An essential gene for fruiting body initiation in the basidiomycete Coprinopsis cinerea is homologous to bacterial cyclopropane fatty acid synthase genes. Genetics. 2006;172:873-84.

23. Wälti M, Villabla C, Buser RM, Grünler A, Aebi M, Künzler M. Targeted gene silencing in the model mushroom Coprinopsis cinerea (Coprinus cinereus) by expression of homologous hairpin RNAs. Eukaryot Cell. 2006;5:732-44.

24. de Sena-Tomás C, Navarro-González M, Kües U, Pérez-Martin J. A DNA damage checkpoint pathway coordinates the division of dikaryotic cells on the ink cap mushroom Coprinopsis cinerea. Genetics. 2013;195:47-57.

25. Day PR, Anderson GE. Two linkage groups on Coprinus lagopus. Genet Res. 1961;2:414-23.

26. Lukens L, Yicun H, May G. Correlation of genetic and physical maps at the A mating type locus of Coprinus cinereus. Genetics. 1996;144:1471-7.

27. Kües U, Tymon AM, Richardson WVJ, May G, Gieser PT, Casselton LA. A mating-type factors of Coprinus cinereus have variable numbers of specificity genes encoding two classes of homeodomain proteins. Mol Gen Genet. 1994;245:45-52.

28. Parsons JF, Jensen PY, Pachikara AS, Howard AJ, Eisenstein E, Ladner JE. Structure of Escherichia coli aminodeoxychorismate synthase: architectural conservation and diversity in chorismate-utilizing enzymes. Biochemistry. 2002;41:2198-208.

29. Bera AK, Atanasova V, Dhandra A, Ladner JE, Parsons JF. Structure of aminodeoxychorismate synthase from Stenotrophomonas maltophilia. Biochem. 2012;51:10208-217

30. Semmelmann F, Straub K, Nazet J, Rajendran C, Merkl R, Sterner R. Mapping allosteric communication network of aminodeoxychorismate synthase. J Mol Biol. 2019:431:2718-28.

31. He Z, Stigers Lavoie KD, Bartlett PA, Toney MD. Conservation of mechanism in three chorismate-utilizing enzymes. J Am Chem Soc. 2004;126:2378-85.

32. Kües $U$, James TY, Vilgalys $R$, Challen MP. The chromosomal region containing pab-1, mip, and the A mating type locus of the secondarily homothallic homobasidiomycete Coprinus bilanatus. Curr Genet. 2001;39:16-24

33. Muraguchi H, Ito Y, Kamada T, Yanagi SO. A linkage map of the basidiomycete Coprinus cinereus based on random amplified polymorphic DNAs and restriction length polymorphisms. Fungal Genet Biol. 2003:40:93-102.

34. Zhang Y, Morar M, Ealick SE. Structural biology of the purine biosynthetic pathway. Cell Mol Life Sci. 2008;65:3699-724.

35. Samant S, Lee H, Ghassemi M, Chen J, Vook JL, Mankin AS, et al. Nucleotide biosynthesis is critical for growth of bacteria in human blood. PLoS Pathog. 2008;4:e37.

36. Rolfes RJ. Regulation of purine nucleotide biosynthesis: in yeast and beyond. Biochem Soc Trans. 2006;34:786-90.

37. West MG, Barlowe CK, Appling DR. Cloning and characterization of the Saccharomyces cerevisiae gene encoding NAD-dependent 5,10-methylenetetrahydrofolate dehydrogenase. J Biol Chem. 1993;268:153-60.

38. Little JG, Haynes $\mathrm{RH}$. Isolation and characterization of yeast mutants auxotrophic for 2'-deoxythymidine 5'-monophosphate. Mol Gen Genet. 1979:168:141-51.

39. Güldener U, Koehler GJ, Haussmann C, Bacher A, Krocke J, Becher D, et al. Characterization of the Saccharomyces cerevisiae Fol 1 protein: Starvation for C1 carrier induces pseudophyphal growth. Mol Biol Cell. 2004;15:3811-28.

40. Mancini R, Saracino F, Busceni G, Fischer M, Schramek N, Bracher A, et al. Complementation of the fol2 deletion in Saccharomyces cerevisiae by human and Escherichia coli genes encoding FTP cyclohydrolase I. Biochem Biophys Res Comm. 1999;255:521-7.
41. Cherest $H$, Thomas D, Surdin-Kurjan Y. Polyglutamylation of folate coenzymes is necessary for methionine biosynthesis and maintenance of intact mitochondrial genome in Saccharomyces cerevisiae. J Biol Chem 2000;275:14056-63.

42. Huang T, Barclay BJ, Kalman TJ, von Borstel RC, Hastings PJ. The phenotype of a dihydrofolate reductase mutant of Saccharomyces cerevisiae. Gene. 1992:121:167-71.

43. Piper MD, Hong S, Ball GE, Dawes IW. Regulation of the balance of one-carbon metabolism in Saccharomyces cerevisiae. J Biol Chem. 2000;275:30987-95

44. Saint-Marc C, Hürlimann HC, Daignan-Fornier B, Pinson B. Serine hydroxymethyltransferase: a key player connecting purine, folate and methionine metabolism in Saccharomyces cerevisiae. Curr Genet. 2015;61:633-40.

45. Rébora K, Desmoucelles C, Borne F, Pinson B, Daignan-Fornier B. Yeast AMP pathway genes respond to adenine regulated synthesis of a metabolic intermediate. Mol Cell Biol. 2001;21:7901-12.

46. Rébora K, Laloo B, Daignan-Fornier B. Revisiting purine-histidine crosspathway regulation in Saccharomyces cerevisiae: A central role for a small molecule. Genetics. 2001;170:61-70.

47. Som I, Mutsch RN, Urbanowski JL, Rolfes RJ. DNA-bound Bas1 recruits Pho2 to activate ADE genes in Saccharomyces cerevisiae. Eukaryot Cell. 2005:4:1725-35.

48. Joo YJ, Kim JA, Baek JH, Seong KM, Han KD, Song JM, et al. Cooperative regulation of Ade3 transcription by Gcn $4 p$ and Bas $1 p$ in Saccharomyces cerevisiae. Cell. 2009;8:1268-77.

49. Moore D. Purine-requiring auxotrophs of Coprinus lagopus (sensu Buller). J Gen Microbiol. 1967:47:163-70.

50. Moore D. Four new linkage groups in Coprinus lagopus. Genet Res. 1967;9:331-42

51. North J. Linkage map of Coprinus cinereus (Schaeff ex Fr.) S. F. Gray. In: O'Brien SJ, editor. Genetic maps. Book 3 Lower eukaryotes. New York: Cold Spring Harbor Laboratory Press; 1990. p. 340-5.

52. Casselton LA. Genetics of Coprinus. In: Kück U, editor. Genetics and biotechnology. The Mycota, vol. II. Berlin: Springer; 1995. p. 35-48.

53. Alic M, Clark EK, Kornegay JR, Gold MH. Transformation of Phanerochaete chrysosporium and Neurospora crassa with adenine biosynthetic genes from Schizophyllum commune. Curr Genet. 1990;17:305-11.

54. Alic M, Mayfield MB, Akileswaran L, Gold MH. Homologous transformation of the lignin-degrading basidiomycete Phanerochaete chrysosporium. Curr Genet. 1991:19:491-4.

55. Giasson L, Specht CA, Milgrim C, Novotny CP, Ulrich RC. Cloning and comparison of the Aa mating-type alleles of the basidiomycete Schizophyllum commune. Mol Gen Genet. 1989;218:72-7.

56. Wang W, Kappock TJ, Stubbe J, Ealick SE. X-ray crystal structure of glycinamide ribonucleotide synthetase from Escherichia coli. Biochem. 1998;37:15647-62.

57. Sampei G, Baba S, Kanagawa M, Yanai H, Ishii T, Kawai H, et al. Crystal structures of glycinamide ribonucleotide synthetase, PurD, from thermophilic eubacteria. J Biochem. 2010;148:429-38.

58. Kanagawa M, Baba S, Watanabe Y, Kuramitsu S, Yokoyama S, Sampei G, Kawai G. Crystal structures and ligand binding of PurM proteins from Thermus thermophilus and Geobacillus kaustophilus. J Biochem. 2016;159:313-21.

59. Fawaz MV, Topper M, Firestone SM. The ATP-grasp enzymes. Biorg Chem. 2012;39:185-91.

60. Sikorski RS, Hieter P. A system of shuttle vectors and yeast host strains designed for efficient manipulation of DNA in Saccharomyces cerevisiae. Genetics. 1989;122:19-27.

61. Green JM, Matthews RG. Folate biosynthesis, reduction, and polyglutamylation and in the interconversion of folate derivatives. EcoSal Plus. 2013. https://doi.org/10.1128/ecosalplus.3.6.3.6.

62. Kües U, Klaus MJ, Polak E, Aebi M. Multiple co-transformation in Coprinus cinereus. FGN. 2001;48:32-4

63. Kilaru S, Hoegger PJ, Kües U. The laccase multi-gene family in Coprinopsis cinerea has seventeen different members that divide into two distinct subfamilies. Curr Genet. 2006:50:45-60.

64. Rühl M, Majcherczyk A, Kües U. Lcc1 and Lcc5 are main laccases secreted in liquid cultures of Coprinopsis cinerea strains. Antonie Van Leeuwenhoek. 2013;103:1029-39. 
65. Pan K, Zhao N, Yin Q, Zhang T, Xu X, Hong Y, et al. Induction of a laccase Lcc9 from Coprinopsis cinerea by fungal coculture and its application on indigo dye decolorization. Bioresour Technol. 2014;162:45-52.

66. Xu GF, Wang JJ, Yin Q, Fang W, Xiao YZ, Fang ZM. Expression of a thermo and alkali-philic fungal laccase in Pichia pastoris and its application. Prot Expr Purific. 2019;154:16-24.

67. Hu J, Zhang YL, Xu Y, Sun QY, Liu JJ, Fang W, et al. Gongronella sp. W5 elevates Coprinopsis cinerea laccase production by carbon source syntrophism and secondary metabolite induction. Appl Microbiol Biotechnol. 2019;103:411-25.

68. Yin Q, Zhou G, Peng C, Zhang YL, Kües U, Liu JJ, et al. The first fungal laccase with an alkaline $\mathrm{pH}$ optimum obtained by directed evolution and its application in indigo dye colorization. AMB Exp. 2019;9:151.

69. Kertesz-Chaloupková K, Walser PJ, Granado JD, Aebi M, Kües U. Blue light overrides repression of asexual sporulation by mating type genes in the basidiomycete Coprinus cinereus. Fungal Genet Biol. 1998;23:95-109.

70. Mösch HU, Graf R, Schmidheini T, Braus GH. Three GCN4 responsive elements act synergistically as upstream and as TATA-like elements in the yeast TRP4 promoter. EMBO J. 1990;9:2951-7.

71. Raymond CK, Pownder TA, Sexson SL. General method for plasmid construction using homologous recombination. Biotechniques. 1999;26:134-41.

72. Wang J, Chen Y, Dong Y, Fang W, Fang Z, Xiao Y. A simple and efficient method for successful gene silencing of HspA1 in Trametes hirsuta AH282. Antonie Van Leeuwenhoek. 2017;110:1527-35.
73. Larkin MA, Blackshields G, Brown NP, Chenna R, McGettigan PA, McWilliam H, et al. Clustal W and Clustal X version 20. Bioinformatics. 2007:23:2496-7.

74. Tamura K, Stecher G, Peterson D, Filipski A, Kumar S. MEGA6: molecular evolutionary genetics analysis version 6.0. Mol Biol Evol. 2013;30:2725-9.

75. Roux B, Walsh CT. p-Aminobenzoate synthesis in Escherichia coli: kinetic and mechanistic characterization of the aminotransferase PabA. Biochem. 1992;31:6904-10.

76. Rayl EA, Green JM, Nichols BP. Escherichia coli aminodeoxychorismate synthase: analysis of pabB mutations affecting catalysis and subunit association. BBA Prot Struct Mol Enzymol. 1996;1295:81-8.

\section{Publisher's Note}

Springer Nature remains neutral with regard to jurisdictional claims in published maps and institutional affiliations.
Ready to submit your research? Choose BMC and benefit from:

- fast, convenient online submission

- thorough peer review by experienced researchers in your field

- rapid publication on acceptance

- support for research data, including large and complex data types

- gold Open Access which fosters wider collaboration and increased citations

- maximum visibility for your research: over $100 \mathrm{M}$ website views per year

At BMC, research is always in progress.

Learn more biomedcentral.com/submissions 